\title{
USOS HISTORIOGRÁFICOS DOS CÓDICES MIXTECO-NAHUAS
}

\author{
Eduardo Natalino dos Santos \\ Doutor em História Social-FFLCH/USP e membro do \\ Centro de Estudos Mesoamericanos e Andinos/USP (CEMA/USP)
}

\section{Resumo}

O objetivo do artigo é delinear e analisar os diferentes usos dos códices mixteco-nahuas por historiadores e outros estudiosos nas últimas cinco décadas. Para isso, dividiremos esses estudiosos em três grupos, definidos pela presença de características comuns em suas formas de abordar os códices. Ao mesmo tempo, apontaremos os alcances e restrições de suas abordagens e sugeriremos alguns critérios e estratégias para usos adequados desse tipo de fonte nas pesquisas históricas.

\section{Pallavras-Chave}

Códices mesoamericanos • Códices mixteco-nahuas • Historiografia mesoamericanista • Fontes pictoglíficas • História da Mesoamérica.

\section{Abstract}

The aim of this article is to delineate and analyse the distinct uses of the Mixtec and Nahua codices by historians and others scholars in the last five decades. In order to achieve this objective, we will divide the scholars and historians into three groups, based on the presence of common characters in their manners of approach to the codices. At the same time, we will point out the competences and limitations of their approaches and will suggest some criteria and strategies for adequate uses of this type of source in the historical researches.

\section{Keywords}

Mesoamerican codices $\bullet$ Mixtec and Nahua codices $\bullet$ Mesoamericanist historiography $\bullet$ Pictographic sources $\bullet$ Mesoamerican history. 


\section{Introdução}

A produção de escritos que combinavam glifos fonéticos, logográficos e ideográficos com pinturas foi realizada por mais de dois mil anos na Mesoamérica e é considerada uma das características definidoras dessa macro-região cultural. Os escritos pictoglíficos ${ }^{1}$ eram produzidos sobre suportes materiais variados, tais como madeira, cerâmica, osso, pedra, estuque, tecido, pele animal e papel, produzido a partir da casca da figueira (papel amate), da fibra do agave (papel maguey) ou ainda de uma palma chamada iczotl. O papel de origem européia também foi empregado na confecção de manuscritos a partir do século XVI. Tais escritos serviram a distintos objetivos e usos ao longo da história mesoamericana e entre seus principais temas estavam a cosmogonia, a história grupal, os feitos das elites dirigentes e suas linhagens, as guerras, conquistas e fundações de cidades, os prognósticos, as oferendas e os tributos.

Os escritos produzidos sobre tecido, pele animal ou papel eram, em geral, enrolados como pergaminhos ou dobrados como biombos e, sobretudo no caso desses últimos, chamados de amoxtli. Esse termo nahuatl significa papéis colados ou adereçados ${ }^{2}$ e já no século XVI foi traduzido como livro pelos castelhanos, como atesta o Vocabulario de Alonso de Molina. ${ }^{3}$ Uma das características pictóricas mais notória desses manuscritos é a presença de linhas grossas e negras de contorno, que formavam glifos e imagens cujas partes eram pintadas de cores distintas, porém uniformes, isto é, sem sombreamento. Esses escritos têm sido agrupados pelos estudiosos sob a denominação de códices mesoamericanos.

\footnotetext{
${ }^{1}$ Prefiro o termo pictoglífico a pictográfico por evocar explicitamente a combinação entre elementos pictóricos e glíficos, uma das principais características tanto do sistema de escrita mixteco-nahua quanto do maia, dois dos mais importantes e estudados sistemas escriturários mesoamericanos. Mais adiante, trataremos de estabelecer as principais semelhanças e diferenças entre esses dois sistemas e de justificar porque iremos analisar apenas estudos relacionados a códices mixteco-nahuas.

${ }^{2}$ Cf. LEÓN PORTILLA, Miguel. El destino de la palabra: de la oralidad y los códices mesoamericanos a la escritura alfabética. México: El Colégio Nacional \& Fondo de Cultura Económica, 1997, p. 21.

${ }^{3}$ Cf. MOLINA, Alonso de. Vocabulario en lengua castellana y mexicana y mexicana y castellana. Estudo preliminar Miguel León Portilla. 4ª edição, México: Editorial Porrúa, 2001, p. 5v.
} 
O conjunto dos códices mesoamericanos é composto por cerca de uma dúzia de manuscritos pré-hispânicos e por mais de cinco centenas de coloniais. São considerados como pré-hispânicos os códices Borgia, Cospi, Fejérváry-Mayer, Laud e Vaticano B, que formam o grupo Borgia ${ }^{4}$, e os códices Becker $n^{o}$. 1 , Bodley, Colombino, Nuttall e Viena, que formam o Grupo Nuttall. Todos esses manuscritos procedem da região de Cholula, Tlaxcala e oeste de Oaxaca, da qual procedem também o Códice Selden, do grupo Nuttall, mas cuja datação é controversa. Do altiplano central mexicano provêm os códices Borbónico e Aubin, dois manuscritos de formato, estilo e características tradicionais, mas cuja datação também é controversa. ${ }^{5}$ Os manuscritos produzidos em todas essas regiões, apesar da existência de diversas línguas, serviam-se de um mesmo sistema escriturário, relativamente distinto do maia e chamado de mixteconahua. Da região maia procedem mais três códices pré-hispânicos: o Dresde, o Paris e o Madrid, formado pelos códices Cortesiano e Troano e, por isso, chamado também de Tro-cortesiano. ${ }^{6}$

Entre as centenas de códices coloniais, há desde manuscritos com material, formato, e temática tradicionais, relacionados principalmente ao sistema mixteco-nahua, até aqueles que apresentam fortes influências da pintura, da escrita e do modo de encadernação ocidentais. No primeiro caso estariam os códices Borbónico e Tonalamatl Aubin e no segundo os códices Magliabechiano e Vaticano A, entre muitos outros.

\footnotetext{
${ }^{4} \mathrm{O}$ grupo Borgia foi definido em 1887 por Eduard Seler e seu mais completo estudo foi de Karl Antony Nowotny, na famosa obra Tlacuilolli. Essa obra permaneceu apenas em alemão até fins de 2004, quando foi traduzida ao inglês por George Everett e Edward Sisson e publicada pela Oklahoma Press. Parece que os trabalhos de Nowotny, por fim, estão sendo reconhecidos como importantes exemplos de análise de códices e traduzidos a outros idiomas. Infelizmente, ainda não tivemos tempo de incorporar a obra Tlacuilolli em nossas análises, pois suas influências metodológicas seguramente estão presentes nas obras reunidas e analisadas em nosso terceiro grupo de estudiosos, sobretudo nas de Gordon Brotherston.

${ }^{5}$ Cf. SANTOS, Eduardo Natalino dos. Calendário, cosmografia e cosmogonia nos códices e textos nahuas do século XVI. Tese de doutorado. Orientadora Janice Theodoro da Silva. São Paulo: Departamento de História da FFLCH - USP, 2005, p. 90.

${ }^{6}$ Cf. GLASS, John B. A survey of native Middle American pictorial manuscripts. In: WAUCHOPE, Robert (editor geral) \& CLINE, Howard F. (editor do volume). Handbook of Middle American Indians. vol. 14. Austin e Londres: University of Texas Press, 1975, p. 12.
} 
O objetivo deste artigo é delinear e analisar os diferentes usos que os historiadores e outros estudiosos têm dispensado aos códices mixteco-nahuas nas últimas cinco décadas e, a partir disso, propor uma espécie de tipificação desses usos historiográficos, apontando seus limites e alcances, suas vantagens e desvantagens, suas adequações e inadequações. Nosso objetivo, portanto, não é produzir uma história das abordagens dispensadas aos códices por todos os estudiosos desde o século XVIII ou XIX, mas realizar um exercício analítico sobre um conjunto de estudos históricos restrito e exemplar para propor um "mapeamento" crítico das principais e atuais tendências de emprego desse tipo de manuscrito.

Realizar esse tipo de análise tomando em conta todo o conjunto de códices mesoamericanos e a grande quantidade de estudos produzidos sobre eles seria um propósito demasiado amplo para um único pesquisador e fugiria aos limites de um artigo. Para termos uma vaga idéia do volume de estudos existente sobre os códices e textos alfabéticos ${ }^{7}$ de origem indígena mesoamericana, basta dizer que o levantamento feito por John B. Glass, embora abarque apenas as obras publicadas até o fim dos anos sessenta, possui mais de mil e oitocentos itens, entre livros e artigos. ${ }^{8}$ Sendo assim, para realizar este exercício analítico-tipológico, limitar-nosemos a um conjunto de obras que terá o caráter de amostragem historiográfica. ${ }^{9}$

${ }^{7}$ À primeira vista, essa expressão parece um pleonasmo. No entanto, seu emprego servirá para diferenciarmos esses manuscritos dos códices, que consideramos e chamaremos de textos pictoglíficos.

${ }^{8}$ Cf. GLASS, John B. Annotated references. In: WAUCHOPE, Robert (editor geral) \& CLINE, Howard F. (editor do volume). Handbook of Middle American Indians. vol. 15. Austin e Londres: University of Texas Press, 1975, pp. 537-724.

${ }^{9}$ As obras historiográficas que serviram de amostra foram lidas durante minha pesquisa de mestrado e de doutorado. As leituras realizadas durante o mestrado, entre 1997 e 2000, contemplaram principalmente os estudos que tratavam dos textos alfabéticos produzidos pelos religiosos castelhanos ou pelos indígenas mesoamericanos durante o século XVI. Nessa ocasião, estava realizando uma comparação entre as formas como os supostos mitos e deuses mesoamericanos haviam sido abordados nesses dois conjuntos de escritos. Embora estivesse utilizando apenas textos alfabéticos como fontes, tive contato com um grande número de estudos que analisavam os códices pictoglíficos, pois é muito comum que esses dois tipos de fontes sejam estudados em conjunto pelos mesoamericanistas. Além disso, algumas das fontes alfabéticas eram parte de códices pictoglíficos, ou seja, eram suas glosas ou textos explicativos. Cf. SANTOS, Eduardo Natalino dos. Deuses do México indígena. Estudo comparativo entre narrativas espanholas e nativas. São Paulo: Editora Palas Athena, 2002. Na pesquisa de doutorado, entre 2000 e 2005, utilizei códices pictoglíficos e textos alfabéticos nahuas do século XVI como fontes. Neles, analisei comparativamente a presença de três complexos conceituais fundamentais ao pensamento nahua: o calendário, a cosmografia e a cosmogonia, bem 
Além dessas limitações no universo historiográfico a ser analisado, a complexidade do tema - isto é, o uso dos códices mixteco-nahuas como fonte histórica - e a grande variedade de soluções apresentadas pelos diversos estudiosos exigem que partamos de algumas questões previamente estabelecidas para realizar esse exercício. Tais questões abordarão problemas e polêmicas relacionados especificamente aos estudos mesoamericanistas e, ao mesmo tempo, a discussões teórico-metodológicas mais amplas e que interessam aos historiadores em geral, pois dizem respeito às formas de uso dos registros pictóricos ou dos escritos não-alfabéticos como fontes na pesquisa histórica. As principais questões que pautarão nossas análises podem ser resumidas da seguinte maneira:

A - Produção, circulação e utilização primária dos manuscritos. O autor do estudo considerou os contextos originais de produção, circulação e uso dos diversos tipos de códices pictoglíficos? Levou em conta que tais códices eram, sobretudo na época pré-hispânica e no início do período Colonial, parte de um sistema institucionalizado de produção e manutenção de saberes que era mantido e gerenciado pelas elites dirigentes mesoamericanas?

$B$ - Posicionamento textual. As pinturas e glifos foram analisados de maneira contextualizada, isto é, considerando-se sua localização no interior do manuscrito e o tipo de códice em que se encontravam?

C-Sentidos historicamente atribuídos. A interpretação e leitura das imagens e glifos basearam-se em sentidos pré-estabelecidos por teorias e sistemas analíticos de origem ocidental ou, ainda, em significados supostamente imanentes às formas e cores? Ou, ao contrário, procurou fundamentar-se nos sentidos que possivelmente seriam atribuídos a tais imagens e glifos em seus contextos originais de produção e uso?

$D$ - Articulação com fontes de outra natureza. Como a análise articulou os códices com fontes de outra natureza, tais como textos alfabéticos? As pinturas e glifos dos códices foram utilizados apenas para confirmar infor-

como suas transformações durante o século XVI e suas relações com as concepções de tempo, espaço e passado. Cf. SANTOS, Eduardo Natalino dos. Calendário, cosmografia e cosmogonia nos códices e textos nahuas do século XVI. Tese de doutorado. Orientadora Janice Theodoro da Silva. São Paulo: Departamento de História da FFLCH - USP, 2005. 
mações obtidas em textos alfabéticos ou possibilitaram a inferência de informações originais?

Em suma, não se trata de abarcar todos os aspectos teóricos e metodológicos que poderiam ser observados e apontados no trato que os autores dos estudos analisados dispensaram aos manuscritos pictoglíficos, mas de verificar as soluções que empregaram diante de questões previamente traçadas e que têm como centro a problemática do uso de fontes pictóricas e glíficas pelo historiador. Verificar o modo como os autores solucionaram tais questões ou constatar que as ignoraram - será o ponto de partida para caracterizar distintas maneiras de empregar os códices pictoglíficos. Isso, por sua vez, poderá fundamentar reflexões sobre os limites e alcances de cada maneira ou sobre critérios e estratégias mais adequados para o uso desse tipo de fonte nas pesquisas históricas.

\section{I - A instauração dos estudos acadêmicos dos códices pictoglíficos e as dife- renças e semelhanças entre o sistema maia e o mixteco-nahua}

Embora nosso objetivo seja analisar as formas de emprego dos códices mixteco-nahuas nos estudos produzidos nas últimas quatro ou cinco décadas, é importante dizer algo sobre o estabelecimento acadêmico desses estudos, bem como acerca das semelhanças e diferenças entre tais códices e os manuscritos maias. Isso porque algumas abordagens atuais, assim como algumas polêmicas irresolutas, fundamentam-se nesses estudos anteriores e nas diferenças e semelhanças entre o sistema escriturários maia e o mixteco-nahua.

É muito difícil estabelecer com precisão a época de início dos estudos dos códices mesoamericanos, pois desde o século XVI esses manuscritos vêm sendo utilizados por europeus ou por americanos como fontes de informação sobre os povos que os produziram. Entre os primeiros ocidentais que tentaram entendê-los e utilizá-los em seus escritos, ainda nos séculos XVI e XVII, destacam-se os religiosos regulares castelhanos, sobretudo franciscanos e dominicanos. Tais religiosos pretendiam, entre outras coisas, converter os povos mesoamericanos ao cristianismo e enquadrá-los na história universal cristã. Para a primeira tarefa era necessário conhecer os usos e costumes locais e combater aqueles que fossem considerados idolátricos. Para a segunda, era preciso conhecer suas histórias passadas e saber, por exemplo, se eram descendentes de uma das tribos perdidas de Israel ou se eram pagãos que descendiam 
diretamente de Cam, um dos filhos de Noé. Em ambos os casos, os códices pictoglíficos e os especialistas nativos em sua leitura e confecção foram utilizados como fontes de informação por religiosos como Toribio de Benavente, Pedro de los Ríos, Diego Durán, Bernardino de Sahagún, Diego de Landa, Juan de Torquemada e José de Acosta, alguns dos quais citaram ou reproduziram partes dos manuscritos mesoamericanos em suas obras. ${ }^{10}$

Nessa mesma época, além das tradições de pensamento e escrita mesoamericanas ${ }^{11}$ continuarem a existir e a produzir manuscritos em escrita tlacuilolli ${ }^{12}$, descendentes das elites locais que haviam sido educados pelos missionários passaram a produzir textos alfabéticos baseados em manuscritos pictoglíficos e a transcrever as leituras dos sábios e especialistas com o alfabeto latino. Essas atividades contribuíam para que os novos senhores político-tributários da região, isto é, os castelhanos, os reconhecessem como membros de antigas linhagens dirigentes e, por vezes, os aceitassem como nobres que intermediariam as relações com o restante da população indígena. ${ }^{13}$ De maneira geral, esse foi o caso

\footnotetext{
${ }^{10}$ Analisamos de maneira detalhada as obras de Bernardino de Sahagún, Diego Durán e José de Acosta durante a pesquisa de mestrado. Cf. SANTOS, Eduardo Natalino dos. Deuses do México indígena. Estudo comparativo entre narrativas espanholas e nativas. São Paulo: Editora Palas Athena, 2002.

${ }^{11}$ Por tradições de pensamento e escrita estamos nos referindo a um conjunto em funcionamento de organizações, grupos, instituições ou indivíduos que se dedicavam de modo sistemático, mas não necessariamente exclusivo, à construção, manutenção, transformação e veiculação de explicações socialmente aceitas acerca das origens e funcionamento do Mundo e da sociedade. Na Mesoamérica, em geral, tais indivíduos, grupos ou instituições eram parte das elites dirigentes e se serviam dos registros pictoglíficos.

${ }^{12} \mathrm{O}$ termo nahuatl tlacuilolli é um substantivo e adjetivo que significa escrita-pintura ou pintado-escrito e refere-se ao resultado da ação de um tlacuilo, isto é, de um escribapintor. Os dois termos nahuas derivam do verbo cuiloa, que significa escrever-pintar. Veremos que empregar o termo escrita para se referir ao sistema mixteco-nahua não é apenas um problema de preferência terminológica, pois envolve princípios e pressupostos teóricos que afetam a análise das fontes em tlacuilolli. Tratamos detalhadamente desse tema em SANTOS, Eduardo Natalino dos. Calendário, cosmografia e cosmogonia nos códices e textos nahuas do século XVI. Tese de doutorado. Orientadora Janice Theodoro da Silva. São Paulo: Departamento de História da FFLCH - USP, 2005, pp. 74-88.

${ }^{13}$ Tratamos em detalhe das transformações e continuidades na produção de explicações históricas pelas elites nahuas de tempos coloniais em SANTOS, Eduardo Natalino dos. As tradições históricas indígenas diante da conquista e colonização da América: transformações e continuidades entre nahuas e incas. In: Revista de História. Departamento de História, FFLCH-USP. São Paulo: Humanitas \& FFLCH - USP, n ${ }^{\circ}$ 150, $1^{\circ}$. semestre de 2004, pp. 157-207.
} 
de Antonio Valeriano de Azcapotzalco, de Dom Fernando de Alva Ixtlilxochitl, de Alonso Vegerano de Cuauhtitlan, de Martin Jacobita de Texcoco, de Pedro de San Bonaventura de Cuauhtitlan e de Chimalpahin Cuauhtlehuanitzin, entre muitos outros. ${ }^{14}$

Desde o século XVI, mas sobretudo a partir do século XVII, os códices pictoglíficos tornaram-se também objetos de desejo de colecionadores, alguns dos quais publicaram inventários de suas coleções e trechos de seus manuscritos, bem como algumas parcas e problemáticas explicações sobre seus conteúdos. Em geral, tais explicações não eram produzidas pelos próprios colecionadores, mas encomendadas a letrados e religiosos que se dedicavam, como parte de seu trabalho ou por interesse humanista, à história, línguas, usos e costumes dos povos indígenas americanos. Entre esses colecionadores e estudiosos, destacam-se Sigüenza y Góngora, no século XVII, Lorenzo Boturini, Francisco Javier Clavijero e Lino Fábrega, no século XVIII. A tradição dos colecionadores de códices chegou até o século XIX, época em que se destacam os nomes do Lorde Kingsborough, de Brasseur de Bourbourg, de José Fernando Ramírez, de Faustino Galicia Chimalpopoca e de Joseph Marius Alexis Aubin. Esse último é considerado um dos precursores dos estudos acadêmicos sobre os códices do México central, pois publicou, ainda em meados do século XIX, tentativas de interpretar comparativamente suas pinturas e elementos glíficos, bem como cópias litográficas completas de sete manuscritos. ${ }^{15}$

No entanto, os estudos sobre os códices mesoamericanos passaram a adotar as bases teórico-metodológicas modernas - das recém-criadas disciplinas de História e Arqueologia - apenas no último quartel do século XIX. Sendo assim, apesar do muito que deviam aos escritores indígenas, aos religiosos e aos colecionadores dos séculos anteriores, podemos dizer que os trabalhos acadêmicos sobre os códices pictoglíficos surgem ou se consolidam nesse mo-

\footnotetext{
${ }^{14}$ Informações sucintas e precisas sobre os escritos alfabéticos produzidos durante o período Colonial pelos indígenas mesoamericanos, ou sobre eles, podem ser obtidas em GIBSON, Charles \& GLASS, John B. A census of Middle American prose manuscripts in the native historical tradition. In: WAUCHOPE, Robert (editor geral) \& CLINE, Howard F. (editor do volume). Handbook of Middle American Indians. vol. 15. Austin e Londres: University of Texas Press, 1975, pp. 322-400.

${ }^{15}$ Cf. GLASS, John B. A survey of native Middle American pictorial manuscripts. In: WAUCHOPE, Robert (editor geral) \& CLINE, Howard F. (editor do volume). Handbook of Middle American Indians. vol. 14. Austin e Londres: University of Texas Press, 1975, pp. 19-26.
} 
mento. ${ }^{16}$ Os primeiros manuscritos a serem analisados sob a influência dessas novas disciplinas foram os códices mixtecos da região de Oaxaca e os códices nahuas do altiplano central mexicano, cujos estudos, por sua vez, influenciaram as primeiras análises dos códices maias. Entre os primeiros acadêmicos especializados nos códices das antigas civilizações do México e América Central $^{17}$, podemos destacar Manuel Orozco y Berra, Alfredo Chavero, León de Rosny, Ernst Förstemann, Francisco del Paso y Troncoso, Eduard Seler, Zelia Nuttall e Alfonso Caso.

Uma das grandes inovações introduzidas nos estudos dos códices mesoamericanos por esses primeiros historiadores e arqueólogos, além dos procedimentos teórico-metodológicos recomendados pelas novas disciplinas acadêmicas, como a crítica documental, foi a combinação sistemática das análises dos manuscritos pictoglíficos com os estudos de fontes alfabéticas e com os dados oriundos das pesquisas arqueológicas e etnográficas. Como um dos grandes exemplos desse tipo de combinação, podemos citar os estudos de Alfonso Caso sobre os códices do ocidente de Oaxaca, publicados a partir de 1930 e que influenciaram grande parte dos estudiosos contemporâneos e das décadas seguintes. ${ }^{18}$

Os estudos realizados entre o último quartel do século XIX e a primeira metade do século XX com essa combinação de fontes e dados propiciaram grandes avanços na decifração dos códices mixteco-nahuas, sobretudo na de seus glifos toponímicos, onomásticos e calendários, cujas leituras tornaram-

\footnotetext{
${ }^{16}$ Nessa época, os estudiosos passaram a contar também com o Congresso Internacional de Americanistas. Sua primeira edição foi realizada na França, em 1875. Em sua quarta edição, na Espanha, em 1881, houve uma grande exibição de códices que se encontravam em coleções e bibliotecas desse país. Cf. Ibidem.

${ }^{17}$ A utilização do termo Mesoamérica e a consciência dessa unidade cultural entre os estudiosos se tornaram mais palpáveis somente depois dos anos de 1940, com os estudos de Paul Kirchhoff sobre as reflexões de Clark Wissler e de Eduard Seler. Cf. KIRCHHOFF, Paul. Mesoamérica: sus límites geográficos, composición étnica y caracteres culturales. In: Suplemento de la Revista Tlatoani. México: Sociedad de Alumnos de la Escuela Nacional de Antropología e Historia, nº. 3, 1960.

${ }^{18}$ Entre suas inúmeras obras, podemos destacar: El pueblo del Sol. 13a . edição, México: Fondo de Cultura Económica, 1994. / Los calendarios prehispánicos. México: Instituto de Investigaciones Históricas - UNAM, 1967. / Reyes y reinos de la Mixteca. 2 vols. México: Fondo de Cultura Económica, 1977-1979.
} 
se razoavelmente bem estabelecidas desde então. Tais estudos também estabeleceram que tais códices combinavam glifos fonéticos, logográficos e ideográficos com pinturas, e que os glifos logográficos e ideográficos e as pinturas eram predominantes - se bem que muitos signos visuais podem ser uma e outra coisa ao mesmo tempo e a natureza de muitos deles permanece, ainda hoje, sujeita a polêmicas.

Por outro lado, acredita-se hoje que a ênfase desses estudos nos aspectos astronômicos e calendários e a interpretação da maioria dos conjuntos pictóricos como representações de deuses - muitos dos quais entendidos como evocações de corpos celestes - tenham sido inadequadas. Esse tipo de interpretação é comumente conhecido como astralista e teve em Eduard Seler um de seus maiores expoentes. ${ }^{19}$

Esses procedimentos de pesquisa e viés de interpretação passaram aos recéminaugurados estudos maias e foram aplicados aos códices e estelas oriundos da porção oriental da Mesoamérica. ${ }^{20}$ As principais conclusões desses primeiros estudos foram que a escrita maia, assim como a mixteco-nahua, era predominantemente ideográfica e que o conteúdo predominante dos códices e estelas era de caráter matemático-astronômico e calendário. Consequientemente, os maias passaram a ser vistos como um povo extremamente pacífico e contemplativo, características que ainda hoje lhes são atribuídas em muitos livros didáticos.

Nos meios acadêmicos, essa visão durou apenas até as décadas de 1950 e 1960, quando os trabalhos de Yuri Knorozov, Heinrich Berlin e Tatiana Proskouriakoff começaram realmente a decifrar os glifos maias, derrubando as leituras ideográficas e a exclusividade da interpretação astralista. ${ }^{21}$ Esses estu-

${ }^{19}$ Cf. REYES GARCÍA, Luis. Dioses y escritura pictográfica. In: Arqueología Mexicana. Códices prehispánicos. Direção científica Joaquín García-Bárcena e outros. México: Editorial Raíces \& INAH \& CONACULTA, vol. IV, nº. 23, 1997, pp. 24-33.

${ }^{20}$ Entre o fim do século XIX e as primeiras décadas do século XX, os estudos arqueológicos, lingüísticos e históricos apenas começavam a delimitar com mais clareza a existência de uma relativa unidade histórico-cultural entre as centenas de sítios arqueológicos encontrados na porção leste da Mesoamérica. A essa unidade foi dado o nome de região cultural maia, uma das partes em que se subdivide a Mesoamérica.

${ }^{21}$ A base do processo de decifração fonética dos glifos maias foi o abecedário presente na Relación de las cosas de Yucatán, obra composta pelo frei Diego de Landa no século XVI. Essa obra perdeu-se após sua morte e foi reencontrada em Madri apenas em 1861, pelo abade Brasseur de Bourbourg. Cf. COE, Michael D. El desciframiento de los glifos mayas. Tradução Jorge Ferreiro. 4a . reimpressão, México: Fondo de Cultura Económica, 2001. 
diosos mostraram a enorme presença de conteúdos relacionados à história grupal e dinástica nos escritos maias, principalmente nas estelas, que versavam sobre as conquistas, guerras e linhagens dirigentes. Além disso, mostraram também que a escrita obedecia a um sentido de leitura padrão e era de índole mista, isto é, composta por glifos fonéticos, logográficos e ideográficos, mas com predomínio de glifos fonéticos e, depois, logográficos. ${ }^{22}$

Devido à presença predominante dos glifos fonéticos e de um sentido de leitura relativamente padronizado ${ }^{23}$, os trabalhos de decifração do sistema de escrita maia avançaram rapidamente e seus resultados se mostraram menos sujeitos a polêmicas e controvérsias elementares, presentes ainda hoje nos estudos dos códices mixteco-nahuas, nos quais predominam os glifos ideográficos e pinturas e não há um sentido de leitura único e válido para todos os manuscritos. Isso, apesar dos contextos de produção dos escritos maias serem muito menos conhecidos do que os nahuas e mixtecos, pois no momento da chegada dos castelhanos havia poucos centros urbanos maias em funcionamento. Por outro lado, a existência vigorosa de povos maias que atualmente falam as línguas grafadas nos códices e estelas, ou derivadas delas, tais como o iucateco, o quiché, o chontal, o tzotzil, o tzeltal e o cakchiquel, facilitou o avanço na decifração e catalogação dos glifos, sobretudo dos fonéticos.

Dessa forma, desde meados do século XX, os estudos dos escritos maias tornaram-se muito específicos, pois dependiam do aprendizado de uma língua maia em particular, e ganharam uma grande autonomia em relação aos estudos de códices e inscrições mixteco-nahuas. Desde essa época, a existência dessas duas tradições de estudo - que contam com formações diferentes e com a existência de universos bibliográficos distintos - faz com que poucos pesquisadores circulem entre elas ou sejam especialistas em ambas. Por esses motivos, iremos nos concentrar unicamente em uma das tradições de estudo, a dos códices mixteco-nahuas, com a qual estamos mais familiarizados.

Embora os contextos de produção, uso e circulação dos códices mixteconahuas sejam mais bem conhecidos do que os maias, principalmente devido

\footnotetext{
${ }^{22}$ Cf. LONGHENA, María. Maya script: a civilization and its writing. Tradução Rosanna M. Giammanco Fongia. Nova Iorque: Abbeville Press, 2000.

${ }^{23}$ Em geral, os glifos maias são lidos da esquerda para a direita, do topo para baixo e em pares de colunas.
} 
ao enorme número de textos alfabéticos em castelhano, nahuatl ou outras línguas indígenas transliteradas, os avanços no entendimento de seus mecanismos de leitura e de parte de seus glifos ideográficos estiveram mais sujeitos a polêmicas elementares e basilares. Isso se deve, principalmente, ao predomínio dos glifos ideográficos e das pinturas, cujas leituras dependiam de tradições orais, bem como à inexistência de um sentido universal de leitura ${ }^{24}$ e à dificuldade de estabelecer quais signos visuais são pinturas e quais são glifos fonéticos, ideográficos ou logográficos - ou, dito de outra forma, em que situações os signos grafados operam como pinturas ou como glifos fonéticos, ideográficos e logográficos, pois muitos deles transitam entre essas categorias ou acumulam, por exemplo, sentidos fonéticos e ideográficos.

Não obstante essas dificuldades, um grande número de estudiosos continuou a se debruçar sobre essas fontes nos últimos cinqüenta anos e a produzir uma quantidade significativa de estudos. Alguns deles deram continuidade às abordagens que vigoraram até as primeiras décadas do século XX, outros revisaram parcialmente esses antigos resultados e alguns outros propuseram formas completamente distintas de analisar os códices pictoglíficos mixteconahuas. Esses esforços geraram uma verdadeira explosão na quantidade de estudos e publicações sobre tais manuscritos na segunda metade do século XX.

As obras que serão analisadas na seqüência, embora não dêem conta da totalidade dessa produção, servirão de amostragem das principais linhas e polêmicas nesse campo de pesquisa. Acreditamos que para efetivar o "mapeamento" crítico das abordagens atuais e mais importantes, como propusemos de início, é mais significativo agrupar as obras analisadas por afinidades teórico-metodológicas do que cronologicamente. Esse tipo de agrupamento permitirá uma percepção mais clara das diferentes escolas ou tradições de uso e interpretação de tais fontes, bem como de alguns de seus pressupostos teóricos e limites analíticos. Antes, porém, convém lembrar que seria impossível agrupar as obras de diversos estudiosos em relação às formas de utilização

\footnotetext{
${ }^{24}$ Isso não significa que cada manuscrito mixteco-nahua não possua um sentido de leitura, bem como indicações internas que permitem estabelecê-lo, tais como as indicações fornecidas pelos glifos calendários e cosmográficos. Cf. SANTOS, Eduardo Natalino dos. Calendário, cosmografia e cosmogonia nos códices e textos nahuas do século $X V I$. Tese de doutorado. Orientadora Janice Theodoro da Silva. São Paulo: Departamento de História da FFLCH - USP, 2005.
} 
dos códices sem apelar para reduções profundas e generalizações amplas e, desse modo, sem cometer graves injustiças em face dos detalhes e da riqueza de muitas delas. No entanto, não há outro modo de fazê-lo num artigo.

\section{II - Uso de fragmentos descontextualizados e subordinados a macro-teorias}

O estudioso mexicano Rubén Bonifaz Nuño propõe explicitamente uma maneira de analisar as imagens mesoamericanas em geral, a qual, portanto, também se aplicaria às pinturas e glifos dos códices. Bonifaz Nuño não acredita que os povos mesoamericanos possuíssem um sistema de escrita e, assim, o único caminho para utilizar suas imagens como fontes históricas seria uma espécie de leitura iconográfica, baseada claramente em algumas considerações de Panofsky, mas acrescidas de uma grande dose de nacionalismo.

O estudioso nomeia sua proposta de hipótese iconográfica e textual $l^{25}$ e acredita ser o único caminho para livrar o estudo dos povos mesoamericanos do que chama de influências do olhar do conquistador. Para sua execução, Bonifaz Nuño propõe que se analisem conjuntos de imagens comprovadamente pré-hispânicas para definir seus traços e elementos particulares e repetíveis, os quais formariam um sistema de representação, isto é, um grupo de signos recorrentes e articulados com sentidos relativamente bem definidos. Depois, segundo o estudioso, seria necessária uma observação humilde e paciente dos elementos componentes do sistema de representação, a qual, por razões não explicadas, permitiria o entendimento de seus significados. Por fim, se analisariam textos coloniais em busca da descrição ou menção de tais significados, cujas presenças comprovariam que tais textos são representantes autênticos do pensamento pré-hispânico, o que autorizaria sua utilização como fonte histórica não contaminada pelo pensamento europeu. Em suas palavras: "El método que para el estudio de nuestra cultura prehispánica he propuesto, consiste en sólo tener por auténticos los textos contenidos en fuentes escritas, cuando su contenido coincide con imágenes plasmadas en las piezas arqueológicas cuya autenticidad no admite duda, ya que fueron hechas antes de la invasión europea." ${ }^{26}$

\footnotetext{
${ }^{25}$ Utilizaremos o itálico para citar expressões que se encontram de modo recorrente nas obras historiográficas analisadas.

${ }^{26}$ BONIFAZ NUÑO, Rubén. Cosmogonía antigua mexicana. México: Coordinación de Humanidades - UNAM, 1995, p. 101.
} 
A partir da afirmação e da síntese que fizemos acima, pode-se perceber que a proposta de Rubén Bonifaz Nuño possui muitos aspectos, no mínimo, problemáticos. Não iremos abordar diretamente os mais genéricos, tais como seu nacionalismo - presente ao afirmar que os mexicanos atuais são herdeiros diretos da cultura pré-hispânica e que assim estariam mais aptos a estudar as imagens desse período - ou suas simplificações pejorativas sobre as transformações dos povos indígenas no período Colonial - presentes ao conceituar as complexas alterações político-culturais desse período como desvios de uma cultura original e autêntica ou como contaminação. ${ }^{27}$ Iremos nos deter nas afirmações igualmente problemáticas que o autor faz ao propor um método de análise das imagens mesoamericanas e uma forma de articulá-las às fontes alfabéticas.

Em duas de suas obras mais importantes, Bonifaz Nuño afirma que quatro formas são inquestionavelmente recorrentes no conjunto das imagens mesoamericanas pré-hispânicas: a humana, a ofídia, a felina e a ornitológica. ${ }^{28}$ Segundo sua interpretação, resultante da observação humilde e paciente, tais formas significariam, respectivamente, a matéria da ação divina, a união entre deuses e homens, as águas incriadas e a elevação da própria criação. Esses sentidos se confirmariam no texto colonial intitulado Histoire du Mechique, considerado então como o escrito que representaria de maneira mais autêntica o pensamento pré-hispânico.

Ao apresentar tais significados para as imagens analisadas, Bonifaz Nuño não considera seus contextos de produção, uso e circulação e tampouco, no caso das imagens provenientes de códices, seus posicionamentos textuais. ${ }^{29}$ O autor não explica como é possível partir da observação e do isolamento de

\footnotetext{
${ }^{27}$ A crença de Bonifaz Nuño que os mexicanos atuais são herdeiros diretos das culturas pré-hispânicas e sua obstinação em tentar separar o que seria autenticamente indígena da influência estrangeira também se projetam sobre suas análises da historiografia, que se dividiria simplesmente em dois tipos: a nacional e a estrangeira. Essa última se caracterizaria por submeter o mundo mexicano a erros importados. Cf. BONIFAZ NUÑO, Rubén. Imagen de Tláloc. México: El Colégio Nacional, 1992.

${ }^{28}$ Cf. Cosmogonía antigua mexicana. México: Coordinación de Humanidades - UNAM, 1995. I Olmecas: esencia y fundación - Hipótesis iconográfica y textual. México: El Colegio Nacional, 1992.

${ }^{29}$ Ver, por exemplo, o uso que o autor faz de algumas imagens dos códices Vaticano $B$ e Borgia. Cf. BONIFAZ NUÑO, Rubén. Cosmogonía antigua mexicana. México: Coordinación de Humanidades - UNAM, 1995, pp. 111-112.
} 
algumas formas recorrentes no universo imagético mesoamericano e chegar aos seus significados gerais e, supostamente, não contaminados pela influência européia. Sendo assim, ao eleger alguns elementos como recorrentes e ao atribuir-lhes significados obtidos por meio do que chama de observação humilde e paciente, o autor parece acreditar que as formas são portadoras de significados universais e imanentes, que independeriam de seus usos e contextos de inserção e cujos sentidos emanariam delas próprias e seriam acessíveis ao estudioso que as observasse por um longo tempo. Na realidade, parece que tais significados derivam do texto Histoire du Mechique, além de derivarem também da mitologia e filosofia clássicas, áreas de estudo conhecidas pelo autor. ${ }^{30}$ Dessa forma, o procedimento de Bonifaz Nuño ao articular imagens e textos alfabéticos é, na verdade, o inverso do que declara, ou seja, o autor parte de narrativas alfabéticas sobre a cosmogonia mesoamericana e, à partir delas, busca imagens e formas pré-hispânicas que poderiam ser relacionadas aos seus conteúdos. Sendo assim, as imagens são empregadas, praticamente, para ilustrar informações obtidas em textos coloniais - e também em escritos sobre a mitologia grega e o pensamento pré-socrático.

De maneira geral, as obras de Serge Gruzinski procuram explicar o processo de transformação cultural desencadeado pela conquista e colonização castelhana da região do atual México ou as maneiras como as culturas nativas foram entendidas pelo pensamento cristão. No primeiro caso, parte da hipótese que a convivência entre castelhanos e mesoamericanos ocasionou uma grande pluralidade de práticas de origens distintas, que foram modificadas por meio de criações improvisadas ou pela justaposição de elementos exóticos. No entanto, devido a um certo predomínio da cultura ocidental, cujos fundamentos não são citados de maneira explícita pelo autor, as sociedades nativas tiveram que se adaptar à irrupção do Ocidente mais do que esse às sociedades nativas. ${ }^{31}$ Dessa

\footnotetext{
${ }^{30}$ Vale notar que a Histoire du Mechique é, praticamente, o único texto empregado por esse autor para atribuir significados às imagens mesoamericanas. Pudemos demonstrar em outra ocasião que a estrutura narrativa e a seleção temática desse texto são muito diferentes das formas tradicionais nahuas e muito parecidas às que se encontram nos escritos dos religiosos castelhanos. Dessa forma, entre os textos alfabéticos de origem nahua, a Histoire du Mechique parece ser um dos mais influenciados pelas demandas, curiosidades e perguntas de origem européia. Cf. SANTOS, Eduardo Natalino dos. Calendário, cosmografia e cosmogonia nos códices e textos nahuas do século XVI. Tese de doutorado. Orientadora Janice Theodoro da Silva. São Paulo: Departamento de História da FFLCH - USP, 2005.

${ }^{31}$ Parece-nos evidente que tal predomínio ancorava-se nas alianças e vitórias políticomilitares dos castelhanos e aliados indígenas - que para pactuar com os cristãos aceita-
} 
forma, as antigas elites e instituições mesoamericanas, responsáveis pela manutenção da memória e do saber, teriam se adaptado às novidades, perseguições e imposições dos cristãos, alterando suas próprias visões e práticas por meio de adoções de elementos estrangeiros modificados (interpretados), formando uma cultura mestiça ou híbrida, distinta das duas que lhe deram origem. No segundo caso, ao tratar das maneiras como as culturas nativas foram entendidas pelo pensamento cristão, Gruzinski busca explicitar, por vezes de forma muito precisa e contundente, como os povos mesoamericanos foram inseridos em um espaço intelectual inventado pelo Ocidente e explicados por meio de conceitos que lhes seriam exóticos, como religião, superstição, crença, culto, sacrifício, adoração, deus, ídolo, idolatria, cerimônia e outros. ${ }^{32}$

Para a realização desses propósitos, Gruzinski - por vezes em parceria com Carmen Bernand - utiliza principalmente os textos castelhanos e, de maneira pontual, algumas imagens extraídas de quadros e murais e, também, de códices pictoglíficos. Tais imagens são selecionadas e servem principalmente para comprovar informações obtidas nos textos alfabéticos, assim como para fortalecer suas teorias sobre a junção entre elementos culturais modificados, de origem ocidental ou mesoamericana. É o que ocorre, por exemplo, num dos capítulos do livro La colonización de lo imaginario, intitulado La pintura y la escritura. Nele, o autor menciona algumas páginas de códices pré-hispânicos, como o Zouche-Nuttall, apenas para mostrar, com base em textos castelhanos e em algumas outras imagens extraídas de códices coloniais, as altera-

ram formalmente sua religião - sobre outros grupos indígenas. Tais vitórias, em geral, precediam os processos de catequese e conversão e a instalação das instituições castelhanas, que assim gozavam de superioridade política em relação às instituições nativas. Dessa forma, a irrupção do Ocidente na América indígena deve-se antes a vitórias político-militares do que a uma suposta superioridade cultural, que aparece de maneira implícita em algumas obras de Serge Gruzinski, nas quais se abordam as transformações culturais geradas pelo convívio entre castelhanos e indígenas, mas não se explicitam suficientemente as hierarquias políticas envolvidas nessas relações. Cf. La guerra de las imágenes: De Cristóbal Colón a "Blade Runner" (1492-2019). Tradução Juan José Utrilla. México: Fondo de Cultura Económica, 1994.

${ }^{32}$ Cf. BERNAND, Carmen \& GRUZINSKI, Serge. De la idolatría. Una arqueologia de las ciencias religiosas. Tradução Diana Sánchez F. México: Fondo de Cultura Económica, 1992. / GRUZINSKI, Serge. La guerra de las imágenes: De Cristóbal Colón a "Blade Runner” (1492-2019). Tradução Juan José Utrilla. México: Fondo de Cultura Económica, 1994. / GRUZINSKI, Serge. La colonización de lo imaginario. Sociedades indígenas y occidentalización en el México español, siglos XVI - XVIII. Tradução Jorge Ferreiro. $2^{\mathrm{a}}$. edição, México: Fondo de Cultura Económica, 1995. 
ções geradas pela colonização castelhana no sistema mixteco-nahua, que teriam gerado formas mestiças de expressão plástica e escritural.

Sendo assim, ao extrair e utilizar apenas algumas imagens ou páginas dos códices, o autor minora seus valores posicionais, pois desconsidera os significados relacionais que poderiam ter em meio dos textos pictoglíficos, isto é, no transcurso de uma longa mensagem cifrada, da qual cada imagem era apenas uma parte. Da mesma forma, Gruzinski deixa de atentar também para os significados que a tais imagens seriam atribuídos em leituras específicas, isto é, em atos e práticas sociais particulares que envolviam um sistema de escrita a serviço das elites dirigentes mesoamericanas - embora cite que os códices eram parte de um sistema institucionalizado de expressão, com funções socialmente definidas, como o controle material-econômico e a manutenção de privilégios. ${ }^{33}$

$\mathrm{O}$ uso pontual e descontextualizado que Serge Gruzinski faz de algumas imagens dos códices mixteco-nahuas talvez se relacione ao seu ceticismo quanto às possibilidades de leitura dos relatos codificados nos glifos e pinturas desses manuscritos. Em suas palavras: “As inscrições mesoamericanas, por mais sofisticadas que sejam, não foram inteiramente decifradas e são de pouca valia para empreender uma reconstituição histórica." ${ }^{34}$ Na mesma página dessa obra, escrita em parceria com Carmen Bernand, os autores vaticinam: "Tudo o que sabemos sobre as civilizações antigas procede, desta forma, dos conquistadores europeus.". Serge Gruzinski justifica seu ceticismo no fato de tais escritos, supostamente, não possuírem guias de leitura e que, desse modo, "Pretender pasar través del espejo y captar a los indios fuera de Occidente es un ejercicio peligroso, con frecuencia impraticable e ilusorio.". 35 Por essas afirmações, po-

\footnotetext{
${ }^{33}$ Cf. GRUZINSKI, Serge. La colonización de lo imaginario. Sociedades indígenas y occidentalización en el México español, siglos XVI - XVIII. Tradução Jorge Ferreiro. $2^{\mathrm{a}}$. edição, México: Fondo de Cultura Económica, 1995, pp. 15-76.

${ }^{34}$ BERNAND, Carmen \& GRUZINSKI, Serge. História do Novo Mundo. Da descoberta à conquista uma experiência européia (1492-1550). Tradução Cristina Muracho. São Paulo: Edusp, 1997, p. 17.

${ }^{35}$ GRUZINSKI, Serge. La colonización de lo imaginario. Sociedades indígenas y occidentalización en el México español, siglos XVI - XVIII. Tradução Jorge Ferreiro. $2^{\mathrm{a}}$. edição, México: Fondo de Cultura Económica, 1995, p. 13. Tais argumentos são muito frágeis ou de natureza retórica, pois o fato de não haver um entendimento completo das inscrições mesoamericanas não anula tudo o que já se sabe sobre elas e os avanços realizados em sua decifração. Prova disso são, por exemplo, os estudos sobre a história dos centros maias do período Clássico e sobre a história dos reinos de Oaxaca, fundamentados nos escritos pictoglíficos e nas fontes arqueológicas.
} 
demos dizer que o estudioso acredita ser impossível obter informações com a leitura e interpretação dos códices pictoglíficos que já não estejam nos textos alfabéticos e, sendo assim, o primeiro grupo de fontes serviria apenas para confirmar ou ilustrar as informações que estariam no segundo.

Pelo exposto acima, podemos observar que as obras de Rubén Bonifaz Nuño e de Serge Gruzinski podem ser agrupadas por apresentarem algumas posturas semelhantes no tratamento dispensado aos códices pictoglíficos, não obstante as enormes diferenças entre seus objetivos: separar os elementos préhispânicos dos cristãos e chegar ao autenticamente indígena, no caso do primeiro, e mostrar a formação de uma cultura híbrida por meio da junção de elementos modificados e provenientes de dois mundos distintos, no caso do segundo. A síntese que apresentaremos abaixo, pautada pelas quatro questões iniciais, procurará mostrar mais claramente as características comuns das formas como ambos tratam os códices pictoglíficos mixteco-nahuas. Acreditamos que ela contribuirá para explicitar as razões que nos levaram a agrupar suas obras nesta parte e a chamar a forma como utilizam os códices de "uso de fragmentos descontextualizados e subordinados a macro-teorias". Aproveitaremos também para tecer algumas considerações sobre os alcances e limites desse tipo de uso.

A - Produção, circulação e utilização primária dos manuscritos. Os dois autores, principalmente Serge Gruzinski, citam os contextos de uso, produção e circulação dos códices pictoglíficos, mas minoram ou desconsideram sua importância no momento da análise das imagens. Sendo assim, os múltiplos sentidos que poderiam ser atribuídos a uma determinada imagem por grupos sociais diversos ou em atos sociais distintos não são valorizados de maneira significativa nas obras dos dois autores - no caso de Bonifaz Nuño, não são sequer mencionados como uma possibilidade de investigação e pesquisa.

$B$ - Posicionamento textual. Nos dois casos, mas sobretudo no de Rubén Bonifaz Nuño, predominam análises de imagens isoladas que resultam em explicações que desconsideram o valor posicional dos signos visuais em meio das inscrições pictoglíficas. Ao desconsiderar o posicionamento textual da imagem ou glifo, quase que automaticamente desconsideram também o tipo de manuscrito ao qual as imagens analisadas pertencem. Tais manuscritos se dividiam em tipos razoavelmente bem delimitados, como os livros de anais (xiuhamatl) ou os livros da conta dos dias e dos destinos (tonalamatl), os quais eram lidos e utilizados em circunstâncias relativamente bem diferentes e que certamente influenciavam no significado das suas imagens e glifos. 
C - Sentidos historicamente atribuídos. Como a importância do contexto de produção, uso e circulação do códice e o valor posicional que a imagem ocupa no interior dele são minorados, predomina a tendência de buscar sentidos estáveis e que confirmem macro-teorias previamente traçadas, como a da mestiçagem ou a do humanismo da religião mesoamericana. ${ }^{36}$ Tal postura não deixa muito espaço para preocupações e perguntas historicamente mais específicas, tais como: qual significado seria atribuído pelos tonalpouhque mexicas (sábios especializados em prognósticos) do início do século XVI à imagem de Mictlantecuhtli (Senhor do Inframundo) que aparece na décima trezena de dias do tonalamatl (livro da conta dos dias e do destino) ao serem consultados por um pochteca (comerciante) que buscava saber sobre sua próxima viagem?

$D$ - Articulação com fontes de outra natureza. Nas obras dos dois autores predomina o uso de fontes alfabéticas, seguido pelo uso de imagens em geral. Entre essas imagens, estão alguns conjuntos pictoglíficos retirados de códices e que geralmente são analisados de maneira isolada, descontextualizada e subordinada aos sentidos apreendidos nos textos alfabéticos - ou às macro-teorias apontadas acima. Esse tipo de uso pode induzir à pressuposição que os significados das imagens e glifos dos códices somente podem ser pesquisados por meio de textos alfabéticos; e não por outros códices pictoglíficos ou por meio de outros tipos de vestígios, como os analisados em estudos arqueológicos. ${ }^{37}$

\section{III - Uso semicontextualizado e subordinado aos conceitos deus, mito e ritual}

As obras de Enrique Florescano são fortemente marcadas pela presença dos conceitos memória, mito e história. Esses três conceitos articulam-se na

\footnotetext{
${ }^{36}$ Uma das principais idéias que Bonifaz Nuño defende nas obras mencionadas acima é a centralidade do homem no pensamento cosmogônico mesoamericano, que ele chama de humanismo da religião mesoamericana.

${ }^{37}$ Os estudos que articulam diversos códices pictoglíficos entre si e com textos alfabéticos de origem indígena serão apontados na parte IV do artigo, intitulada Uso contextualizado de manuscritos produzidos por tradições de pensamento e escrita. Há diversos estudos arqueológicos que procuram relacionar os vestígios materiais encontrados em contextos arqueológicos bem definidos com suas representações nos códices, buscando esclarecer os usos e significados sociais dos objetos e de suas representações ou menções em textos pictoglíficos. Vale conferir, por exemplo, as obras de Eduardo Matos Moctezuma: Muerte a filo de obsidiana. Los nahuas frente a la muerte. 4a . edição, México: Asociación de Amigos del Templo Mayor \& Fondo de Cultura Económica, 1997. / Vida y muerte en el Templo Mayor. $3^{\mathrm{a}}$. edição, México: Fondo de Cultura Económica \& Asociación de Amigos del Templo Mayor, 1998.
} 
proposta que o autor faz para os estudos mesoamericanos: reconstituir as imagens míticas que os povos indígenas elaboraram de seu passado a partir do enorme conjunto de narrativas que chama de memória mexicana; em seguida, separar nelas o que seria histórico - supostamente os relatos verossímeis sobre acontecimentos passados - do que seria mítico - supostamente tudo o que não se encaixaria na delimitação anterior. ${ }^{38}$

Florescano utiliza prioritariamente os textos alfabéticos para tentar recompor as imagens míticas, cujos símbolos nos remeteriam indiretamente a fatos passados ou a formulações simbólicas específicas da cultura e do pensamento mesoamericano. ${ }^{39}$ É o que faz, por exemplo, ao analisar o caso de Quetzalcoatl. A partir de informações obtidas em textos alfabéticos, como a Leyenda de los soles e os Anales de Cuauhtitlan, Florescano caracteriza essa personagem cosmogônica e histórica como uma metáfora do desenvolvimento e dos altos valores dos povos mesoamericanos, tais como as plantas cultivadas, os primeiros reinos e a criação do Mundo e do homem atual. ${ }^{40}$ Depois, sob essa égide, interpreta diversos conjuntos pictoglíficos que possuem algum elemento passível de ser relacionado a esse complexo de idéias, considerando a todos como representações de Quetzalcoatl e de seus atributos.

Desse modo, sua utilização das fontes pictoglíficas é, em geral, secundária e pontual, servindo principalmente para confirmar informações, conclusões e significados obtidos por meio dos textos alfabéticos, bem como por meio dos pressupostos que acompanham os conceitos centrais em suas análises, como deus ou ritual. ${ }^{41}$ Não é raro na obra desse estudioso que tais conclusões e significados sejam tidos como sentidos universalmente aplicáveis às diversas imagens dos códices pictoglíficos, procedimento que desconsidera a posição textual e o tipo de códice

\footnotetext{
${ }^{38}$ Cf. FLORESCANO, Enrique. Memoria mexicana. 2a . edição, México: Fondo de Cultura Económica, 1994.

${ }^{39}$ Cf. FLORESCANO, Enrique. Mito e história en la memoria mexicana - Texto datilografado do discurso apresentado em seu ingresso na Academia Mexicana de História como membro de número, em 18 de julho de 1989.

${ }^{40}$ Cf. FLORESCANO, Enrique. Sobre la naturaleza de los dioses mesoamericanos. Disponível em <http://www.nexos.com.mx/nexos/dic228/temcen/tc1.html > Consultado em 23 de março de 1998.

${ }^{41}$ Por exemplo, um dos pressupostos que acompanha o conceito deus é a idéia que tais seres possuem atributos mais ou menos estáveis, os quais, em geral, devem estar codificados nas vestes, adornos e objetos portados.
} 
em que se encontram - embora o tipo de manuscrito e a posição textual sejam citados algumas vezes pelo autor. Para Florescano, tais cenas condensariam os sentidos contidos discursivamente nos textos alfabéticos, dos quais é possível abstrair núcleos míticos ou desentranhar fatos históricos tipicamente mesoamericanos, como, respectivamente, a participação de Quetzalcoatl na criação da humanidade atual e a existência de um rei-sacerdote homônimo durante os episódios que levaram a cidade de Tula à ruína.

Podemos ver que nos usos que Florescano faz dos códices pictoglíficos e dos relatos alfabéticos mesoamericanos juntam-se duas pressuposições muito polêmicas. Primeiro, que é possível separar os elementos míticos - supostamente produtos do pensamento primitivo que atendem às necessidades simbólicas do universo político e religioso nas sociedades não-ocidentais e pré-modernas dos históricos - produto da manutenção de uma relação de verossimilhança entre o ocorrido e o escrito ou relatado - de forma total e dicotômica no interior das explicações acerca do passado. ${ }^{42}$ Segundo, que os conjuntos pictoglíficos dos códices são predominantemente representações dos deuses e de seus atributos ou rituais relacionados. Essa segunda pressuposição é polêmica pois uma série de análises - algumas das quais tratadas na próxima parte-demonstra que muitos desses conjuntos são compostos de glifos fonéticos e ideográficos que faziam parte de um sistema de escrita e, sendo assim, encontram-se articulados para a codificação de um texto ou discurso.

As obras de Doris Heyden, de maneira geral, se caracterizam pela preocupação central em estabelecer o caráter simbólico dos supostos deuses e elementos relacionados, isto é, as qualidades e atributos que não estariam explicitamente declarados nas imagens e relatos sobre os deuses, mas reunidos e codificados neles de forma alegórica. A autora partilha com Florescano o pressuposto de que é possível separar os conteúdos que se referem a acontecimentos reais das elaborações míticas realizadas pelos mexicas e outros povos nahuas na confecção desses símbolos, principalmente no interior dos textos transcritos com o alfabeto latino no período Colonial.

Apoiando-se explicitamente nas teorias de Mircea Eliade acerca do mito e do ritual, Doris Heyden explica, por exemplo, os sentidos das narrativas

\footnotetext{
${ }^{42}$ Explicaremos porque não concordamos com os pressupostos desse tipo de análise na próxima parte.
} 
mexicas sobre a fundação de México-Tenochtitlan, as quais possuiriam um fundo histórico real, mas cujo principal objetivo seria inserir tal episódio em um tempo sagrado e re-convertido em presente por meio do ritual. Em outras palavras, tais narrativas e símbolos relacionados seriam uma tentativa de reviver ou refazer a cosmogonia e transformar Tenochtitlan em uma cópia dos locais de origem, tais como Aztlan, Chicomoztoc ou Culhuacan. ${ }^{43}$

Em um de seus mais importantes trabalhos, a autora utiliza-se de uma conjugação ampla de fontes textuais e pictoglíficas ao analisar o famoso símbolo da fundação de México-Tenochtitlan, no qual se juntariam e sobreporiam elaborações de caráter mítico e histórico. ${ }^{44}$ Apesar da utilização constante de imagens de códices, o modo como Doris Heyden articula as diversas fontes para realizar esse tipo de análise embasa-se num suposto predomínio da tradição oral sobre a escrita na Mesoamérica, principalmente no caso nahua. Essa tradição oral seria auxiliada por ritos, celebrações e pinturas, fato que segundo ela deve servir para que o estudioso subordine o material pictoglífico aos textos alfabéticos ao analisá-los, pois esses últimos se relacionariam mais diretamente com os antigos discursos nahuas.

Esse procedimento analítico pode contribuir para esclarecer os sentidos de imagens pictoglíficas por meio de conceitos, descrições e narrativas encontradas em textos alfabéticos, mas pode, por outro lado, desconsiderar os diferentes contextos pictoglíficos em que as imagens se encontram ao utilizá-las como entidades mais ou menos independentes, o que certamente traz prejuízos para o entendimento de cargas semânticas específicas, atribuídas a uma imagem em leituras de determinados tipos de livros e em situações sociais específicas.

No estudo de outro caso, Doris Heyden utiliza a mesma abordagem. Realiza um levantamento sistemático dos nomes e atributos pelos quais Tezcatlipoca era tratado no mundo nahua, bem como de suas participações na cosmogonia os quais se encontram presentes em textos alfabéticos indígenas e nas obras de Bernardino de Sahagún e outros castelhanos. Depois, Heyden associa as informações obtidas nos textos alfabéticos às imagens pictoglíficas dessa deidade e

\footnotetext{
${ }^{43}$ Cf. HEYDEN, Doris. Las cuevas de Teotihuacan. In: Arqueología Mexicana. Ritos del México prehispánico. Direção científica Joaquín García-Bárcena e outros. México: Editorial Raíces \& INAH \& CONACULTA, vol. VI, nº. 34, 1998, pp. 18-27.

${ }^{44} \mathrm{Cf}$. HEYDEN, Doris. México: orígenes de un símbolo (versión adaptada e ilustrada). México: CONACULTA \& INAH, 1998.
} 
completa sua análise relacionando os significados obtidos nos textos e imagens aos relatos de rituais que se faziam a essa deidade. ${ }^{45}$

Isso mostra como Doris Heyden aprofunda suas análises em temas especificamente mesoamericanos, como Tezcatlipoca ou a fundação de MéxicoTenochtitlan, não obstante a carga de generalidade inerente aos conceitos que emprega para tratar esses temas, como mito, deus e ritual. A autora consegue reunir uma grande quantidade de informações específicas e obtidas sobretudo nos textos alfabéticos, as quais são, sem dúvida nenhuma, importantes ferramentas no estudo dos códices pictoglíficos. No entanto, tais informações são relacionadas às imagens pictoglíficas a que supostamente correspondem sem muita cautela, isto é, sem levar em conta os diferentes meios textuais em que as imagens se encontravam, os distintos tipos de livros a que pertencem e as diversas possibilidades de leituras a que tais livros estavam sujeitos.

Na vastíssima e consistente obra de Alfredo López Austin, os conceitos de mito, deus e ritual também são centrais, bem como a atenção a temas específicos da história e cultura mesoamericana, como Quetzalcoatl, Tollan ou os homens-deuses. Uma das preocupações centrais em suas obras é mostrar a existência de uma religião mesoamericana, supostamente evoluída a partir de um estágio histórico-cultural anterior, no qual predominaria o pensamento mágico. ${ }^{46}$ Valendo-se dessa premissa e procurando embasá-la em dados arqueológicos, López Austin procura caracterizar a organização da religião mesoamericana, os usos políticos de suas ideologias componentes e a relação entre os povos e seus deuses.

Para desenvolver essa tarefa, utiliza-se centralmente dos textos alfabéticos dos séculos XVI e XVII, nos quais, assim como Enrique Florescano e Doris Heyden, tenta separar os chamados acontecimentos históricos dos míticos. Esses últimos resultariam de elaborações narrativas posteriores, que tinham por objetivo central, segundo o autor, adequar os aconteceres históricos aos

\footnotetext{
${ }^{45}$ Cf. HEYDEN, Doris. Tezcatlipoca en el mundo náhuatl. In: Estudios de Cultura Nahuatl. Editor Miguel León Portilla. México: Instituto de Investigaciones Históricas UNAM, vol. 19, 1989, pp. 83-93.

${ }^{46}$ Cf. LÓPEZ AUSTIN, Alfredo. Los milénios da la religión mesomericana (parte I). In: Arqueología Mexicana. Los olmecas. La religión en Mesoamérica. Direção científica Joaquín García-Bárcena e outros. México: Editorial Raíces \& INAH \& CONACULTA, vol. II, $n^{\circ} .12,1995$, pp. 4-15.
} 
padrões dos relatos criacionais e apresentá-los ritualmente. Por exemplo, as narrativas migratórias nahuas presentes em parte dos códices pictoglíficos são, para López Austin, o reviver de eventos anteriores mesclados a símbolos políticos atuais que se deve à necessidade de revitalizar o tempo por meio do ritual e voltar às origens, à história do tempo do mito (in illo tempore) ${ }^{47}$

Em uma de suas obras mais conhecidas, López Austin faz uma espécie de balanço da figura de Quetzalcoatl através dos tempos, tarefa para a qual utiliza centralmente textos alfabéticos, desde os primeiros relatos do século XVI até os estudos historiográficos recentes. ${ }^{48}$ Nela, aponta as múltiplas e contraditórias informações acerca dessa personagem, tida por alguns como homem e por outros como deus, problema que o autor soluciona brilhantemente aplicando o conceito de homem-deus a tal personagem e relacionando-o ao termo nahuatl ixiptla, que significa aquilo ou aquele que se faz imagem e semelhança de algo ou alguém.

Assim como no caso dos dois autores tratados anteriormente, Lopez Austin utiliza prioritariamente as informações e interpretações dos textos alfabéticos, além de estudos arqueológicos, para explicar os sentidos e significados das pinturas em cerâmicas e murais, das esculturas e, também, das imagens dos códices. No entanto, López Austin apresenta os contextos de produção, uso e circulação das fontes de forma mais detalhada do que os dois autores tratados acima, tanto dos textos alfabéticos como dos códices pictoglíficos, e lhes dá um peso maior em suas análises. Isso porque um de seus principais objetivos é entender os usos e funções desses relatos e imagens como elementos ideológicos das elites.

López Austin também demonstra uma maior preocupação em definir e articular teoricamente os conceitos que emprega-deus, religião, rito, ritual-para

\footnotetext{
${ }^{47} \mathrm{O}$ autor também embasa sua explicação em Mircea Eliade, sobretudo no conceito de tempo cíclico das sociedades arcaicas. Cf. LÓPEZ AUSTIN, Alfredo. Hombre-dios: religión y política en el mundo náhuatl. México: Instituto de Investigaciones Historicas - UNAM, 1973. Embora nosso objetivo não seja fazer a crítica da forma como os autores utilizam o conceito de tempo cíclico, é importante apontar sua insuficiência para dar conta da visão de passado dos povos mesoamericanos. Como pudemos demonstrar em outra ocasião, tais povos contabilizavam a diacronia por meio de um sistema calendário preciso e a valorizavam em seus relatos e registros sobre os eventos passados - o que não exclui a presença da sincronia na contabilidade do tempo e em tais relatos e registros. Cf. SANTOS, Eduardo Natalino dos. Calendário, cosmografia e cosmogonia nos códices e textos nahuas do século XVI. Tese de doutorado. Orientadora Janice Theodoro da Silva. São Paulo: Departamento de História da FFLCH - USP, 2005.

${ }^{48}$ Cf. LÓPEZ AUSTIN, Alfredo. Hombre-dios: religión y política en el mundo náhuatl. México: Instituto de Investigaciones Historicas - UNAM, 1973.
} 
explicar e interpretar os fenômenos político-religiosos da Mesoamérica, adaptando-os, muitas vezes, às especificidades dessa área cultural. No entanto, ao buscar a materialização visual desses conceitos nos códices mixteco-nahuas, mesmo que adaptados à realidade mesoamericana, López Austin restringe a análise desses manuscritos aos elementos que supostamente lhes são correlatos. ${ }^{49}$ Por exemplo, ao tratar do deus Quetzalcoatl, refere-se a uma entidade cujo estatuto é especificamente mesoamericano e que se distingue, por exemplo, dos deuses clássicos. No entanto, uma grande quantidade de conjuntos pictoglíficos distintos é automaticamente explicada como manifestações visuais do complexo ideológico relacionado a Quetzalcoatl. Além disso, em outros casos, vem à tona o pressuposto que a maioria das figuras antropomorfas com atavios que constam nos códices correspondam a deuses e seus atributos, fazendo com que diversos conjuntos pictoglíficos sejam isolados de seus contextos escriturários e identificados como representações de figuras divinas.

Sendo assim, López Austin subestima os valores posicionais que as imagens ocupam no interior do registro pictoglífico, bem como seus valores fonéticos ou ideográficos, seja ao buscar o específico homem-deus Quetzalcoatl ou ao identificar uma série de conjuntos pictoglíficos como deuses, atributos e rituais relacionados Desse modo, os sentidos e explicações dos conjuntos pictoglíficos, assim como no caso dos dois autores tratados antes, almejam uma certa universalidade, mesmo que delimitada a casos caracteristicamente mesoamericanos, como o citado homem-deus Topiltzin Quetzalcoatl.

Como vimos, há um importante grupo de estudiosos que interpreta as imagens dos códices pictoglíficos mixteco-nahuas preferencialmente como representações de deuses, rituais e mitos relacionados. ${ }^{50}$ As contribuições desses es-

${ }^{49}$ Cf. Los ritos: un juego de definiciones. In: Arqueología Mexicana. Ritos del México prehispánico. Direção científica Joaquín García-Bárcena e outros. México: Editorial Raíces \& INAH \& CONACULTA, vol. VI, nº 34, 1998, pp. 4-17. / Los rostros de los dioses mesoamericanos. In: Arqueología Mexicana. Los dioses de Mesoamérica. Direção científica Joaquín García-Bárcena e outros. México: Editorial Raíces \& INAH \& CONACULTA, vol. IV, no. 20, 1996, pp. 6-19.

${ }^{50}$ Diversas outras obras poderiam ser analisadas como parte desse grupo de estudiosos, como as de Eduardo Matos Moctezuma, citadas em nota anterior, e as de Román Piña Chan, o qual compartilha com López Austin as explicações sobre a origem da religião mesoamericana a partir de uma evolução do pensamento mágico, bem como sobre o caráter de homem-deus de Quetzalcoatl de Tula. Cf. PIÑA CHAN, Román. Quetzalcoatl. Serpente emplumada. 5a reimpressão, México: Fondo de Cultura Económica, 1992. 
tudiosos para o conhecimento de complexos fenômenos político-religiosos têm sido fundamentais aos estudos mesoamericanistas. Isso porque procuram apontar as especificidades da história e do pensamento mesoamericanos, apesar de empregarem conceitos que contribuem para produzir uma visão homogênea acerca de sociedades e períodos históricos muito distintos, pois são aplicados a praticamente todos os povos não-ocidentais ou ocidentais pré-modernos. No entanto, por outro lado, pode-se apontar algumas limitações de suas abordagens no que diz respeito ao uso dos códices como fontes históricas. Segundo as quatro questões e problemas que propusemos de início, podemos dizer, de forma geral, e, portanto, injusta em alguns casos, que suas abordagens aos códices pictoglíficos caracterizam-se da seguinte forma:

A - Produção, circulação e utilização primária dos manuscritos. Os estudiosos desse grupo valorizam mais os contextos de uso, produção e circulação dos códices pictoglíficos do que os do grupo anterior, principalmente para explicar os objetivos das tradições narrativas mesoamericanas e, em alguns casos, seus usos ideológicos. Tal valorização ocorre principalmente quando se trata de abordar as fontes em bloco, isto é, como o conjunto da produção de uma determinada tradição narrativa, como a que era mantida pela elite mexica. No entanto, isso não impede que minorem a importância da produção, uso e circulação ao analisarem as imagens e glifos dos códices. Nesse processo, dão maior peso aos pressupostos e capacidades explicativas dos conceitos apontados como centrais em suas abordagens, sobretudo deus e ritual, com os quais qualificam grande parte das imagens pictoglíficas e caracterizam seus supostos usos. Por esse motivo, chamamos a forma como empregam os códices de "uso semicontextualizado e subordinado aos conceitos deus, mito e ritual".

B-Posicionamento textual. Apesar de encontrarmos nas obras dos autores desse grupo algumas referências e citações ao tipo de livro ou contexto textual em que se encontram as imagens pictoglíficas, predominam as análises que desvalorizam seu posicionamento textual. Tais análises relacionam-se a temas específicos da história e da cultura mesoamericanas, mas tendem a produzir sentidos e significados supostamente atribuíveis a todas as imagens semelhantes - por exemplo, às imagens de Quetzalcoatl -, independentemente de seu posicionamento textual em cada um dos códices. 
C-Sentidos historicamente atribuídos. Como a importância do contexto de produção, uso e circulação do manuscrito e o valor posicional das imagens são atenuados, predomina a tendência de buscar sentidos estáveis e de identificar as imagens pictoglíficas pertencentes aos mais diversos códices como entidades divinas e seus acessórios-atributos relacionados. Embora isso seja feito por meio de conceitos que homogeneizam as particularidades dos povos não-ocidentais ou ocidentais não-modernos, vale frisar que os sentidos estáveis atribuídos pelos estudiosos desse grupo às imagens dos códices pictoglíficos, diferentemente do que ocorre com os estudiosos do grupo anterior, tendem a se configurar em torno de temas e elementos particulares da história e da cultura mesoamericanas - por exemplo, a caracterização de Quetzalcoatl como o criador da quinta humanidade, o descobridor do milho e o homemdeus portador dos saberes toltecas.

$D$ - Articulação com fontes de outra natureza. Apesar da ampla utilização de códices pictoglíficos, os autores desse grupo priorizam os textos alfabéticos, no interior dos quais estariam os relatos míticos, cujos símbolos nos remeteriam indiretamente aos eventos históricos ou a outras particularidades da cultura e da história mesoamericana, tais como os usos simbólicos e ideológicos da figura de Quetzalcoatl ou de Tula. Tais símbolos e eventos estariam grafados de outra forma nas imagens pictoglíficas, explicadas, desse modo, fundamentalmente a partir dos conteúdos e informações dos textos alfabéticos. Essa forma de articular os diferentes tipos de fontes se basearia, segundo Doris Heyden, num suposto predomínio da oralidade - grafada parcialmente em textos alfabéticos coloniais - sobre os elementos pictoglíficos do sistema mixteco-nahua. No entanto, veremos que a relação entre oralidade e registro visual em tal sistema era muito mais complexa e não se restringia à subordinação de uma forma de expressão à outra. $\mathrm{Na}$ verdade, pensamos que os entraves para analisar as fontes alfabéticas e pictoglíficas em pé de igualdade repousam nas dificuldades de leitura do segundo grupo, que são muito maiores do que as relacionadas ao primeiro.

\section{IV - Uso contextualizado de manuscritos produzidos por tradições de pensa- mento e escrita}

Atualmente, Miguel León Portilla é um dos mesoamericanistas mais conhecidos e suas obras caracterizam-se por análises comparativas que articulam prin- 
cipalmente textos alfabéticos, mas que também incluem códices pictoglíficos, principalmente em seus trabalhos mais recentes. ${ }^{51}$ Os escritos alfabéticos ou pictoglíficos são tratados por ele como partes de um corpo literário, isto é, de um conjunto formado por escritos que tratam de temáticas distintas e que serviram a usos variados, mas que se relacionam entre si por compartilharem estilos, formas e temas, e também por terem sido produzidos por grupos e instituições sociais semelhantes, ou seja, por escribas e sábios das elites mesoamericanas dos últimos séculos antes do contato ou do primeiro século do período Colonial. ${ }^{52}$ León Portilla acredita que o estudo comparativo dos escritos desse corpo literário permite, com o auxílio de fontes de outra natureza e também dos estudos arqueológicos, o estabelecimento dos estilos de seus componentes, o delineamento do funcionamento e da inserção social das tradições que o produziu, a compreensão dos usos sociais e das leituras a que tais escritos se prestavam e, por fim, o entendimento de seus conteúdos e o conhecimento das especificidades da história e do pensamento mesoamericano.

${ }^{51} \mathrm{Cf}$. El destino de la palabra: de la oralidad y los códices mesoamericanos a la escritura alfabética. México: El Colégio Nacional \& Fondo de Cultura Económica, 1997. I Códices - Los antiguos libros del Nuevo Mundo. México: Aguilar, 2003. Em geral, seus trabalhos são pouco conhecidos em nosso país, à exceção de Visión de los vencidos: relaciones indígenas de la conquista. $2^{\mathrm{a}}$. edição, México: UNAM, 1961. Trata-se de uma coletânea de trechos de textos produzidos por indígenas acerca da violência da conquista castelhana que foi traduzida ao português. Um outro texto do estudioso traduzido ao nosso idioma é: A Mesoamérica antes de 1519. In: BETHELl, Leslie. História da América Latina: América Latina colonial, vol. I. Tradução Maria Clara Cescato. $2^{\text {a }}$. edição, São Paulo: Edusp \& Brasília: Fundação Alexandre Gusmão, 1998. pp. 25-61. Nele, o qual o autor delineia o desenvolvimento dos povos e culturas anteriores aos mexicas e as realizações culturais no período mexica, além de apresentar uma visão geral da Mesoamérica às vésperas da chegada dos europeus, em 1519.

${ }^{52}$ A idéia de um corpo literário nahuatl já se encontrava presente nas obras de Ángel María Garibay K., professor de Miguel León Portilla, mas restringia-se a textos alfabéticos coloniais. As obras de Garibay foram publicadas desde fins dos anos de 1930 e já no início dos anos 1950 resultaram na obra Historia de la literatura náhuatl. México: Editorial Porrúa, 1992, que até hoje é uma referência para o estudo dos textos alfabéticos mesoamericanos do centro do México. Além disso, Garibay foi o responsável pela publicação e por estudos introdutórios das historias de Bernardino de Sahagún (Proemio general. In: SAHAGÚN, Fray Bernardino de, Historia general de las cosas de Nueva España. 9a. edição, México: Editorial Porrúa, 1997. pp. 1-14) e de Diego Durán (Diego Durán y su obra. In: DURÁN, Fray Diego. Historia de las Indias de Nueva España e islas de la tierra firme. 2a . edição, México: Editorial Porrúa, 2 volumes, 1984. pp. IX-XLVII), bem com de uma importante coletânea de textos de origem indígena (Teogonía e historia de los mexicanos: tres opúsculos del siglo XVI. 5a . edição, México: Editorial Porrúa, 1996). 
Em duas de suas obras mais recentes, León Portilla dedica-se a demonstrar as principais características dos diversos tipos de livros pictoglíficos préhispânicos, bem como do pensamento dos grupos e instituições responsáveis por suas produções. ${ }^{53}$ Trata também de delinear as mais importantes alterações e continuidades na produção de escritos na Mesoamérica durante o período Colonial, sobretudo as relacionadas à mudança de sistema escriturário, isto é, ao progressivo abandono da escrita pictoglífica que é acompanhado pela crescente adoção da alfabética. Dentro desse processo, León Portilla busca "mapear" os estilos e tipos de livros e códices e fixar as características próprias do que chama de literatura nahuatl, presentes nos códices pré-hispânicos ou coloniais tradicionais, mas também em muitos textos alfabéticos. Segundo o estudioso, a análise desse processo permite distinguir as alterações de origem européia dos atributos nativos no interior dos textos pictoglíficos e alfabéticos coloniais, muitos dos quais demonstram uma profunda coerência em relação à produção pré-hispânica, indicando que grande parte de suas formas, estilos, temas e informações não foram criados no século XVI. Essa coerência autorizaria os estudiosos a utilizarem esses manuscritos coloniais como "chaves de leitura" para os textos pré-hispânicos de tradições e estilos compatíveis - desde que tal utilização seja acompanhada por críticas filológicas e históricas rigorosas e pela consciência dos problemas envolvidos na transposição de conteúdos grafados pictoglificamente para escritos alfabéticos.

Em outra de suas obras, León Portilla procura fazer uma espécie de história das tradições produtoras dos escritos mesoamericanos, desde as origens olmecas, no segundo milênio a.C., passando pelas tradições teotihuacana, zapoteca, mixteca, maia, tolteca e nahua, e chegando até a época da conquista castelhana. ${ }^{54}$ O autor não reduz sua análise aos códices em pele de veado, papel amate ou tecido - cujos materiais e formatos os tornariam semelhantes aos livros e pergaminhos ocidentais -, mas considera também os baixos-relevos e as pinturas murais e cerâmicas como vestígios de cantos e poemas, de eventos sociais e de saberes sobre os deuses, a astronomia e o calendário. Nessa mesma obra, apon-

\footnotetext{
${ }^{53}$ Cf. El destino de la palabra: de la oralidad y los códices mesoamericanos a la escritura alfabética. México: El Colégio Nacional \& Fondo de Cultura Económica, 1997. I Códices - Los antiguos libros del Nuevo Mundo. México: Aguilar, 2003.

${ }^{54}$ Cf. Literaturas indígenas de México. $2^{\mathrm{a}}$ edição, México: Fondo de Cultura Económica \& Editorial Mapfre, 1992.
} 
ta para a necessidade de compreendermos o sistema calendário para podermos entender a lógica gramatical dos códices pictoglíficos e, desse modo, os contextos textuais em que suas imagens e glifos estão inseridos, pois grande parte desses manuscritos estrutura-se conceitualmente nos cômputos calendários, principalmente os tonalamatl - livros utilizados por sacerdotes especializados em prognósticos - e os xiuhamatl - livros utilizados pelas elites dirigentes para registrar a história de suas linhagens ou cidades.

Desse modo, as análises de León Portilla estabelecem características comuns e conteúdos paralelos entre códices pré-hispânicos, códices coloniais e textos alfabéticos, alguns dos quais seriam "leituras coloniais" de antigos livros pictoglíficos com a participação de indígenas. ${ }^{55}$ Sendo assim, de maneira geral, as interpretações ou leituras de Miguel León Portilla das imagens pictoglíficas tendem a contextualizá-las, em seu meio textual e social, e a vinculá-las ao tipo de livro em que se encontram, procurando, em outras palavras, estabelecer possíveis significados e leituras dentro de um determinado contexto textual-estilístico-social, isto é, formado pelo tipo de livro, pelo uso que dele faziam os especialistas indígenas responsáveis por sua confecção e leitura e também pela inserção social desses especialistas. ${ }^{56} \mathrm{~A}$ aplicação desses critérios e objetivos ao longo de várias décadas de estudos fez com que

\footnotetext{
${ }^{55}$ Exemplos dessas "leituras coloniais" de textos pictoglíficos são a Historia de los mexicanos por sus pinturas, as glosas e textos dos códices Vaticano A e TellerianoRemense, os Anales de Cuauhtitlan e a Leyenda de los Soles. Os dois mais importantes levantamentos dos manuscritos alfabéticos e pictoglíficos mesoamericanos são, respectivamente: GIBSON, Charles. A survey of Middle American prose manuscripts in the native historical tradition. In: WAUCHOPE, Robert (editor geral) \& CLINE, Howard F. (editor do volume). Handbook of Middle American Indians. vol. 15. Austin e Londres: University of Texas Press, 1975. pp. 311-321. / GLASS, John B. \& ROBERTSON, Donald. A census of native Middle American pictorial manuscripts. In: WAUCHOPE, Robert (editor geral) \& CLINE, Howard F. (editor do volume). Handbook of Middle American Indians. vol. 14. Austin e Londres: University of Texas Press, 1975. pp. 81-310.

${ }^{56}$ Sendo assim, podemos dizer que León Portilla busca as especificidades histórico-culturais da Mesoamérica por meio de seus vestígios escritos, apesar de por vezes se referir a elementos do pensamento mesoamericano com conceitos muito genéricos, como o eterno feminino (Toltecáyotl: aspectos de la cultura náhuatl. 5ª edição, México: Fondo de Cultura Económica, 1995), ou de procurar mostrar que os povos dessa região eram culturalmente superiores, assim como os da antiguidade clássica e oriental, pois possuíam literatura e livros (Códices - Los antiguos libros del Nuevo Mundo. México: Aguilar, 2003).
} 
León Portilla trouxesse inúmeras contribuições para a leitura e o entendimento de fontes alfabéticas e pictoglíficas. ${ }^{57}$

Outro conjunto de estudos importante para exemplificar a abordagem dos códices pictoglíficos como membros de um grupo de escritos inter-relacionados foi produzido por Gordon Brotherston, que também se refere a esse grupo como um corpo literário. Suas obras, de modo geral, se caracterizam pela preocupação em entender as potencialidades e usos dos sistemas de escrita mesoamericanos, sobretudo do mixteco-nahua, que o autor prefere chamar de escrita tlacuilolli, bem como por traçar as principais características das concepções mesoamericanas de tempo, espaço, passado, política e história, entre outras.

Segundo esse estudioso, grande parte das dificuldades em entender os códices pictoglíficos advém de uma espécie de preconceito ocidental contra as escritas não-fonéticas ou não-alfabéticas, que se manifesta principalmente de duas formas. Em alguns casos, considerando as imagens que compõem tais sistemas exclusivamente como pinturas e não como signos de uma escrita. Em outros, subestimando os recursos da linguagem visível em proveito de uma visão foneticista, isto é, que analisa as escritas pictoglíficas apenas como um instrumento de transmissão da fala e busca decifrar seus códigos lingüísticos como o de um rébus, uma "linguagem artificial usada para segredos militares, e ignorando qualquer mensagem visual que pudesse estar sendo transmitida.". ${ }^{5}$

\footnotetext{
${ }^{57}$ Por exemplo, a formação dos glifos toponímicos, suas potencialidades conotativas, valores semânticos e representações mais utilizadas nos códices do centro do México são apresentados em LEON PORTILLA, Miguel. Los nobres de lugar en náhuatl. Su morfología, sintaxis y representción glífica. In: Estudios de cultura náhuatl. Editores Miguel León Portilla e outros. México: Instituto de Investigaciones Históricas - UNAM, vol. 15, 1982, pp. 37-72.

${ }^{58}$ BROTHERSTON, Gordon. Traduzindo a linguagem visível da escrita. In: Literatura e Sociedade. São Paulo: Departamento de Teoria Literária e Literatura Comparada da FFLCH - USP, n 4, 1999, p. 79. Segundo Brotherston, tal tendência pode ser observada em boa parte dos estudos dos escritos maias, nos quais alguns símbolos seriam mais adequadamente lidos como ideogramas e não apenas foneticamente. De acordo com esse estudioso, não devemos esquecer que o sistema maia emergiu da base mesoamericana, compartilhada pelo sistema mixteco-nahua, que era utilizado por falantes de diversas línguas e não se ligava foneticamente a nenhuma, fato que garantia o entendimento e penetração de seus conceitos e glifos correspondentes em uma área amplíssima e muito variada em termos étnicos e lingüísticos. Por outro lado, aparentemente com a intenção de combater a subvalorização dos sistemas de escrita mesoamericanos, alguns estudiosos têm assumido como pressuposto que todos os elementos presentes no sistema mixteco-nahua são estritamente fonéticos. Essa é a proposição basilar dos trabalhos de Joaquín Galarza, entre os quais estão: In amoxtli in tlacatl - el libro, el hombre. Códices y vivencias. México: Tava Editorial, 1992. / Los códices mexica-
} 
Em uma série de estudos, Brotherston analisa centralmente os escritos pictoglíficos mesoamericanos e mostra a possibilidade de obtermos informações específicas sobre a história e a cultura de seus produtores e usuários, muitas das quais não se encontram em nenhum relato alfabético colonial, nem mesmo nos produzidos por indígenas ou com sua participação. ${ }^{59}$ Por outro lado, mostra também que os códices pictoglíficos permitem a análise da visão dos povos indígenas sobre temas amplamente tratados pela historiografia com base exclusivamente em fontes castelhanas.

É o caso, segundo ele, da conquista de México-Tenochtitlan, tema estudado sobretudo a partir de fontes castelhanas que, por um lado, desvalorizam a participação dos povos nativos e de Malintzin (Malinche) e, por outro, realçam a de Cortés e seus companheiros. Em um pequeno artigo, Brotherston analisa o Lienzo de Tlaxcala, que apresenta uma visão distinta da conquista das que constam nas fontes de origem castelhana. ${ }^{60}$ Isso porque esse manuscrito

nos. In: Arqueología Mexicana. Códices prehispánicos. Direção científica Joaquín GarcíaBárcena e outros. México: Editorial Raíces \& INAH \& CONACULTA, vol. IV, nº. 23, 1997, pp. 6-13. Esse tipo de proposição, na verdade, termina por validar o juízo que um sistema de registro visual do pensamento ou da fala é uma "verdadeira escrita" somente quando se configura estritamente como a grafia da língua falada.

${ }^{59}$ Entre esses estudos, podemos destacar os que tratam da concepção de passado e da duração das idades do mundo (The year 3113 BC and the Fifth Sun of Mesoamerica: an orthodox reading of the Tepexic Annals. In: AVENI, Anthony F. \& BROTHERSTON, Gordon [editores]. Calendars in Mesoamerica and Peru - Native American computations of timeProceedings 44 International Congress of Americanists, Manchester 1982. Oxford: BAR, 1983), das festas das dezoito vintenas de dias entre os mexicas e de suas relações com as estações do ano (The year in the Mexican codices: the nature and structure of the eighteen feasts. Texto datilografado, 2002), das características dos tipos de livros pictoglíficos e de suas transformações durante o período Colonial (Painted books from Mexico. Codices in UK collections and the world they represent. Londres: British Museum Press, 1995) ou das respostas e interpretações das tradições de pensamento mesoamericanas aos fenômenos ocasionados pela conquista e colonização castelhana (European scholasticism analysed in aztec terms: the case of the Codex Mexicanus. In: Boletim do Centro de Estudos e Documentação sobre o Pensamento Antigo Clássico, Helenístico e sua Posteridade Histórica (CPA). Campinas: Instituto de Filosofia e Ciências Humanas - UNICAMP, ano IV, n. 5/6, pp. 169-180, janeiro/dezembro de 1998 / Indigenous intelligence in Spain's American Colony. In: Forum for modern language studies. St Andrews (Escócia): University of St Andrews Press, vol. XXXVI, no. 3, 2000, pp. 241-253).

${ }^{60}$ Cf. BROTHERSTON, Gordon. La visión americana de la conquista. In: PIZARRO, Ana. América Latina: palavra, literatura e cultura, vol. 1. São Paulo: Fundação Memorial da América Latina \& Campinas: Editora da Unicamp, 1993. pp. 63-84. 
trata as alianças entre os grupos indígenas e castelhanos e as atuações de Malintzin como eventos centrais nos processos de negociação e nos ataques militares a Cholula e México-Tenochtitlan. ${ }^{61}$

Em uma de suas obras mais volumosas e recentes, Brotherston dedica-se a tratar das concepções que os povos de algumas macro-regiões culturais americanas possuíam acerca da gênese do Mundo e do homem, da memória política, do tempo e do espaço. ${ }^{62}$ Trata sobretudo da região mesoamericana, sua especialidade, mas também da andina, amazônica, circuncaribenha e anasazi. Ao tratar da Mesoamérica, utiliza textos pictoglíficos em articulação com alfabéticos indígenas para mostrar como as características definidoras das concepções mencionadas acima eram amplamente compartilhadas pelos diversos povos dessa macro-região, permeando grande parte de seu corpo literário. Segundo ele, essas concepções eram compartilhadas por esses povos devido à existência de relações constantes e antiqüíssimas, bem como à existência de instituições especializadas em sistematizar, produzir, manter e usar politicamente tais concepções - estamos chamando essas instituições de tradições de pensamento e escrita. Os códices pictoglíficos eram parte dos mecanismos de atuação dessas instituições, as quais, por esse motivo, devem ter suas funções sociais analisadas pelo estudioso que busca compreender tais manuscritos.

Ao analisar as imagens dos códices pictoglíficos, Brotherston procura não projetar sobre elas a separação radical entre pintura e escritura, bem como entre signos fonéticos e ideográficos, pois ambas separações relacionam-se a concepções ocidentais que parecem não se adequar aos manuscritos pictoglíficos mixteco-nahuas. Isso porque essas separações tendem, segundo ele, a fazer com que os estudiosos ignorem ou desvalorizem representações que articulam conteúdos genéricos e "abertos” à interpretação - típicos de uma pintura-com idéias bem específicas - típicas de um glifo ideográfico -; ou, ainda, signos visuais que juntam mensagens fonéticas e conceituais. Em outras palavras, Brotherston

\footnotetext{
${ }^{61}$ Gordon Brotherston enfatiza que não se trata de diminuir a importância dos relatos castelhanos, mas de admitir outras vozes e versões sobre um mesmo fenômeno e de compará-las. Para isso, é necessário tratar os registros daqueles que se encontravam fora da tradição intelectual cristã do século XVI de maneira eqüitativa em relação aos cristãos e, na medida do possível, de modo auto-referenciado, isto é, levando em conta seus próprios referenciais histórico-culturais. Cf. Ibidem.

${ }^{62}$ Cf. La América indígena en su literatura: los libros del cuarto mundo. Tradução de Teresa Ortega Guerrero e Mónica Utrilla. México: Fondo de Cultura Económica, 1997.
} 
acredita que devemos ampliar nossa concepção de escrita para entendermos o caso da escrita tlacuilolli, de modo que esse conceito abranja qualquer sistema de representação visual ou táctil (no caso dos quipus) do pensamento ou da fala com convenções, usos, lógica e gramática bem estabelecidos. ${ }^{63}$

É com esses marcos teóricos e tratando de temas especificamente mesoamericanos - por exemplo, os teoamoxtli (livros divinos), os mapas territoriais, a contagem calendária, as eras cosmogônicas, a memória política, Tollan, os toltecas e as epopéias de Quetzalcoatl - que Gordon Brotherston analisa as imagens dos códices pictoglíficos e procura atribuir-lhes sentidos de acordo com as concepções, a gramática, as convenções e a lógica interna da escrita tlacuilolli, bem como segundo as funções e usos sociais que determinados tipos de manuscritos desempenhavam nas mãos de seus produtores e usuários.

As obras de Federico Navarrete Linares mostram que ele também compartilha algumas posturas analíticas com os dois estudiosos mencionados acima. Algumas de suas obras buscam, de maneira geral, entender o que chama de tradições históricas das sociedades nahuas, sobretudo da mexica, como passo fundamental para a compreensão dos textos alfabéticos e pictoglíficos que produziram, como os códices que tratam da migração mexica e da fundação de México-Tenochtitlan.

Dois de seus artigos sintetizam essa preocupação. O primeiro deles, de caráter mais historiográfico, trata de mostrar como os códices pictoglíficos e textos alfabéticos provenientes de tais tradições foram entendidos de maneira inadequada por duas "escolas" interpretativas modernas. ${ }^{64}$ Por um lado, a interpretação mítica ${ }^{65}$, defendendo que Aztlan seria uma projeção de MéxicoTenochtitlan ao passado e que ao ler as fontes teríamos apenas que decifrar seus significados simbólicos. Por outro lado, a histórica ${ }^{66}$, defendendo que

\footnotetext{
${ }^{63}$ Voltaremos a tratar desse problema nas Considerações Finais.

${ }^{64}$ Cf. NAVARRETE LINARES, Federico. Las fuentes indígenas: más allá de la dicotomía entre historia y mito. Disponível em <www.fflch.usp.br/dh/ceveh/public html/biblioteca/artigos/FN-P-A-historiaymito.html > Consultado em 09 de dezembro de 2000.

${ }^{65}$ Representada por Enrique Florescano, entre outros.

${ }^{66}$ Representada principalmente por Alfredo Chavero, um dos pioneiros nos estudos mesoamericanistas que, desde 1877, publicou uma série de fontes alfabéticas e pictoglíficas, como os escritos de Sahagún e os códices Boturini, Aubin e Veytia, ademais de estudos sobre esses manuscritos e também acerca da Pedra do Sol e do sistema calendário. Cf. GLASS, John B. Annotated references. In: WAUCHOPE, Robert (editor geral) \& CLINE, Howard F. (editor do volume). Handbook of Middle American Indians. vol. 15. Austin e Londres: University of Texas Press, 1975. pp. 537-724.
} 
Aztlan existiu e que os mexicas buscavam locais semelhantes para fundar México-Tenochtitlan e que, por esse motivo, devemos ler as fontes como instrumentos críticos que auxiliem na comprovação, ou não, de eventos históricos, isto é, que sucederam no passado conforme apontam os escritos.

Para superar as limitações dessas posturas dicotômicas e parciais e analisar as fontes pictoglíficas e alfabéticas produzidas pelas tradições nahuas de maneira mais contextualizada e completa, o autor propõe que tratemos tais registros como plenamente históricos, isto é, como representações coletivas acerca do passado, as quais, como quaisquer outras, possuem uma relação indireta e mediada com a realidade passada, fundamentada na particularidade dos conceitos mesoamericanos de tempo, espaço, passado, verdade, fato, entre outros, e nos interesses sócio-políticos de seus produtores. Segundo Navarrete Linares, devemos conhecer esses fundamentos para não lançarmos automaticamente os discursos contidos nos códices pictoglíficos e textos alfabéticos indígenas ao campo das narrativas míticas, as quais se definiriam por oposição aos discursos plenamente históricos. Essa divisão tem como premissa fundamental a pressuposição de que as narrativas tachadas de míticas não se fundamentariam na realidade passada, mas no funcionamento da mente primitiva, e que, por outro lado, as narrativas produzidas pela ciência histórica ocidental estariam livres das dimensões simbólica e ideológica e totalmente fundamentadas em eventos passados. ${ }^{67}$

\footnotetext{
${ }^{67}$ Navarrete Linares rechaça os argumentos geralmente utilizados para lançar as tradições histórias indígenas ao campo do mito. Esses argumentos seriam: a deficiência nas técnicas de transmissão da memória histórica, a parcialidade e localismo das fontes, a natureza simbólica e ideológica do discurso sobre o passado e a destruição de outras tradições pelos soberanos mexicas do século XV. O autor contra-argumenta dizendo que, no caso indígena, a transmissão oral poderia funcionar com regras bem determinadas e em meio de instituições políticas seculares e que os códices possuíam uma extrema precisão cronológica, geográfica e onomástica, características que garantiriam continuidades temporais amplas na manutenção de informações sobre o passado. Por outro lado, no caso ocidental, que a escrita fonética não garantiria a veracidade de qualquer escrito histórico nem a fixidez de seus sentidos. Por fim, em ambos os casos, que nada nos próprios escritos permite distinguir inequivocamente entre significados literais e metafóricos, fato que gera a necessidade de uma análise simbólica que no entanto não invalide o caráter histórico dos escritos indígenas ou ocidentais. Cf. NAVARRETE LINARES, Federico. Las fuentes indígenas: más allá de la dicotomía entre historia y mito. Disponível em <www.fflch.usp.br/dh/ceveh/public html/biblioteca/artigos/FN-P-Ahistoriaymito.html > Consultado em 09 de dezembro de 2000.
} 
Ao propor esse tipo de entendimento, mais do que citar o contexto de produção, uso e circulação dos códices pictoglíficos, Navarrete Linares o transforma no próprio cerne de suas leituras e interpretações das imagens desses manuscritos.

Dando continuidade a essa proposta, Navarrete Linares mostra, em outro artigo, como o polêmico tema da queima dos códices pictoglíficos pelos castelhanos poderia ser entendido nos marcos de funcionamento das tradições de pensamento e escrita nahuas. ${ }^{68}$ Sem negar o impacto terrível que as fogueiras de manuscritos pictoglíficos do século XVI tiveram sobre as tradições de pensamento e escrita nativas, pois pretendiam eliminá-las, o autor apresenta fortes indícios de que em tempos pré-hispânicos, por vezes, os tlacuilos e tlamatinime (sábios) destruíam livros velhos após a confecção de novas versões, que seriam politicamente mais adequadas aos tempos presentes. ${ }^{69}$ Desse modo, o autor mostra que o papel dos livros pictoglíficos nas sociedades indígenas mesoamericanas poderia ser muito distinto daquele que geralmente lhe é atribuído: o de algo raro que deveria ser preservado e cujo valor dependeria de sua antiguidade. Tais idéias, juntamente com a de autenticidade, são freqüentemente aplicadas nos estudos dos códices e talvez não tenham sido centrais nas sociedades mesoamericanas, nas quais as substituições e destruições voluntárias e periódicas de manuscritos, e também de outros objetos e das construções, parecem ter sido freqüentes.

Essa particularidade explica-se, segundo Navarrete Linares, pelo fato de que as tradições de pensamento e escrita mesoamericanas eram propriedades de um grupo humano específico, de uma linhagem que a preservava, a modificava e a utilizava para definir sua identidade e para estabelecer e defender sua posição de privilégio, seja no seio da própria sociedade ou no complexo mosaico sócio-político dos povos mesoamericanos. Para essas tradições, a veracidade ancorava-se na ancestralidade e em seus herdeiros e não exclusiva-

\footnotetext{
${ }^{68}$ Cf. Los libros quemados y los libros sustituidos. Disponível em: <www.fflch.usp.br/ dh/ceveh/public html/biblioteca/artigos/fn-a-e-livrosquei.html > Consultado em $09 \mathrm{de}$ dezembro de 2000.

${ }^{69}$ A destruição de manuscritos, sobretudo de anais históricos, promovida pelo soberano mexica Itzcoatl (1427-1440) é o exemplo mais famoso desse tipo de prática em tempos pré-hispânicos. Da mesma forma, as fogueiras de manuscritos promovidas por Juan de Zumárraga poderiam também ter sido interpretadas pelas tradições de pensamento e escrita nahuas como sinais do estabelecimento de um novo poder político, que exigia novas versões históricas.
} 
mente nos livros pictoglíficos, que assim não eram os depositários da verdade - papel que alguns livros desempenham no interior da tradição cristã. ${ }^{70}$

Dessa forma, as leituras desses manuscritos, principalmente dos livros de anais, “...no era el deciframiento silencioso de un texto fijado en un momento histórico determinado (es decir, de un texto con una 'aura'), sino una representación pública y ritual que permitía ver y escuchar el relato de los antiguos, reuniendo los libros pictográficos y las tradiciones orales en un todo más rico que cualquiera de sus partes.". ${ }^{71}$ Desse modo podemos perceber que, para Navarrete Linares, a articulação entre os códices pictoglíficos e a tradição oral era bem mais complexa do que a simples subordinação das imagens e glifos dos códices a discursos sabidos de memória. Em outras palavras, tais imagens e glifos não eram simplesmente um suporte mnemônico pontual e parcial que servia para "detonar" uma narrativa conhecida de memória, pois "...el 'texto' [hablado] no leía la imagen completamente, ni esta podía comprenderse sin la explicación verbal.". ${ }^{72}$

Em sua tese de doutoramento, Navarrete Linares faz um minucioso estudo do funcionamento das tradições históricas dos povos nahuas que se estabeleceram no vale do México e cercanias e consegue mostrar que, ao contrário do que

\footnotetext{
${ }^{70} \mathrm{O}$ entendimento dessa particularidade nos permite perceber também que os indígenas não foram objetos passivos de aculturações durante o processo de adaptação das narrativas pictoglíficas pré-hispânicas a textos alfabéticos. Ao contrário, como eram donos de uma tradição viva cuja continuidade residia na sobrevivência do grupo social que a transmitia, e não na preservação de livros "autênticos", os indígenas procuraram adaptar seus relatos históricos aos marcos da história universal cristã. Cf. Ibidem. Dessa forma, os principais produtores desses escritos, isto é, as elites dirigentes nahuas, poderiam ter seu pensamento entendido pelos castelhanos e provar que eram parte de linhagens que dirigiam essa parte do mundo desde tempos antiguíssimos e que, por vezes, estariam dispostos a continuar a fazê-lo sob a autoridade do rei de Castela para manter determinados privilégios. Essas tradições sucumbiram apenas com a desarticulação e destruição das elites indígenas ao longo do período Colonial, sobretudo depois da segunda metade do século XVII. Cf. SANTOS, Eduardo Natalino dos. Calendário, cosmografia e cosmogonia nos códices e textos nahuas do século XVI. Tese de doutorado. Orientadora Janice Theodoro da Silva. São Paulo: Departamento de História da FFLCH - USP, 2005.

${ }^{71}$ NAVARRETE LINARES, Federico. Los libros quemados y los libros sustituidos. Disponível em: <www.fflch.usp.br/dh/ceveh/public html/biblioteca/artigos/fn-a-elivrosquei.html> Consultado em 09 de dezembro de 2000, sem $\mathrm{n}^{\circ}$. de página.

${ }^{72}$ A palavra entre colchetes foi inserida por mim. NAVARRETE LINARES, FEDERICO. Mito, historia y legitimidad política: las migraciones de los pueblos del Valle de México. Tese de doutoramento. Orientador Alfredo López Austin. México: Facultad de Filosofía y Letras - UNAM, 2000, p. 60.
} 
reivindicam as próprias fontes mexicas, a trajetória, o estabelecimento e a fundação de México-Tenochtitlan não foram eventos excepcionais, mas seguiram padrões comuns que constam em narrativas históricas de outros povos, como os acolhuas, chalcas, colhuas e cuauhtitlancalque. ${ }^{73}$ Segundo o autor, esse tipo de resultado mostra que as análises das fontes indígenas devem sempre estar vinculadas aos estudos de suas tradições produtoras, pois só assim poderemos encarar o discurso histórico presente nos códices como construções sociais com regras, formas, sentidos historicamente determinados e critérios de verdade próprios.

Diversos outros estudiosos poderiam ser agrupados nesta parte por apresentarem algumas posturas analíticas semelhantes às de León Portilla, Brotherston e Navarrete Linares, tais como Ferdinand Anders, Maarten Jansen e Luis Reyes García. ${ }^{74}$ No entanto, isso prolongaria nossa análise além dos limites desejáveis para um artigo. Ademais, acreditamos que as obras analisadas nesta parte constituem-se como uma amostra suficientemente ampla para apresentarmos a existência de um outro tipo de uso dos códices pictoglíficos, o qual podemos sintetizar da seguinte maneira:

A-Produção, circulação e utilização primária dos manuscritos. De maneira geral, uma das idéias centrais dos estudiosos desse grupo é tratar as fontes pictoglíficas como partes inseparáveis de um corpo literário produzido pelas

\footnotetext{
${ }^{73}$ Cf. Ibidem.

${ }^{74}$ Entre suas obras conjuntas, podemos destacar os livros explicativos que acompanham as edições fac-similares dos códices Borbónico, Borgia, Magliabechiano e Vaticano A, publicados desde os anos 1990 em parceria pelas editoras Fondo de Cultura Económica (México) e Adeva (Áustria). Ao estudar e comparar seis tonalamatl, Reyes García aponta que Del Paso y Troncoso e Eduard Seler, ao analisarem as cenas das trezenas dos tonalamatl em fins do século XIX e início do XX, procedem como no século XVI, identificando as imagens centrais como deuses e ao resto dos elementos pictoglíficos como acessórios-atributos dessas deidades. Tal tradição de estudos teve continuidade ao longo do século XX, com Bodo Spranz, que faz um inventário dos acessórios portados pelos deuses nos códices do Grupo Bórgia, e com López Austin, que interpreta tais acessórios e atavios como os atributos intercambiáveis dessas deidades. Para Reyes García "Analizar e interpretar las imágenes de los dioses que aparecen en los tonalamatl fuera de su contexto de lectura mántica es un error metodológico." REYES GARCÍA, Luis. Dioses y escritura pictográfica. In: Arqueología Mexicana. Códices prehispánicos. Direção científica Joaquín García-Bárcena e outros. México: Editorial Raíces \& INAH \& CONACULTA, vol. IV, $\mathrm{n}^{\circ} .23,1997$, p. 33. Isso porque as imagens e conjuntos de glifos que têm sido interpretados como a representação da fusão ou da fissão de deuses, ou ainda como seus acessórios-atributos, representariam, na verdade, a combinação de palavras-chave para a leitura-elaboração de um discurso.
} 
tradições de pensamento e escrita mesoamericanas. Sendo assim, tais fontes devem ser estudadas em conjunto para que umas auxiliem no entendimento de outras e, em grupo, forneçam vestígios sobre as características de suas produções, usos e, portanto, sobre as tradições de pensamento e escrita que as produziram e sobre a sociedade como um todo. Em outras palavras, as obras analisadas nesta parte sugerem que os escritos pictoglíficos somente podem ser analisados e entendidos de maneira adequada se levarmos em conta os marcos de funcionamento de tais tradições, as quais, por sua vez, inseriam-se e atuavam de modos específicos no interior das sociedades mesoamericanas. Sendo assim, mais do que apenas citar o contexto de produção, uso e circulação dos códices pictoglíficos, os autores aqui agrupados o levam em consideração ao interpretar ou propor leituras das imagens e glifos dos códices ou ainda o transformam no centro de suas pesquisas.

$B$ - Posicionamento textual. Na maioria das vezes, os autores deste grupo buscam entender antes os sentidos gerais e normas de leituras dos diversos tipos de textos pictoglíficos para depois propor significados para algum de seus conjuntos de imagens em específico. Em outras palavras, buscam estabelecer possíveis significados e leituras dentro de um determinado contexto textualestilístico-social, marcado sobretudo pelos tipos de livros, pelos usos que deles faziam os especialistas indígenas em suas confecções e leituras e também pela inserção social desses especialistas. Também é consensual entre tais autores que o entendimento do calendário é central para a compreensão dos códices, pois era empregado para organizar e articular seus conjuntos pictoglíficos e fornecer indícios sobre seus sentidos de leitura.

C-Sentidos historicamente atribuídos. Por considerar relevante as esferas de produção, uso e circulação e por valorizar o posicionamento textual, os autores desse grupo tendem a propor leituras e significados historicamente bem circunscritos para as imagens e glifos dos códices. Em outros termos, procuram inserir tais significados e leituras em meio dos marcos funcionais, conceituais e estilísticos que seriam empregados pelas tradições que produziam e utilizavam esses manuscritos. Em suma, os autores agrupados nesta parte acreditam que as análises das fontes pictoglíficas devem estar sempre vinculadas aos estudos das tradições de pensamento e escrita mesoamericanas, pois só assim é possível entender os discursos e narrativas presentes nos códices como construções sociais com regras, formas e sentidos historicamente determinados. 
$D$ - Articulação com fontes de outra natureza. Os autores desse grupo utilizam os códices pictoglíficos para compará-los entre si e com os textos alfabéticos e vice-versa, mas sem a ingênua convicção de que esses são traduções diretas daqueles. Os estudos que realizaram sobre o funcionamento das tradições de escrita das sociedades mesoamericanas, principalmente os de Navarrete Linares, mostraram que a relação existente entre escritos pictoglíficos e oralidade era complexa e não pode ser explicada como a simples utilização de imagens para relembrar um discurso sabido de memória. No entanto, essa complexidade não invalida as correlações presentes entre textos pictoglíficos e alfabéticos coloniais, as quais autorizam o estudioso a buscar parte das leituras dos códices pictoglíficos nesses textos alfabéticos, sobretudo nos de origem indígena.

\section{Considerações finais}

A exposição das abordagens dos três grupos de estudiosos em relação às quatro questões iniciais, bem como as sínteses ao final de cada parte, demonstraram que o segundo e o terceiro grupos, sobretudo o terceiro, utilizam de forma mais adequada os códices pictoglíficos como fontes históricas. Essa conclusão justifica-se por dois motivos.

Em primeiro lugar, se concordamos que as fontes históricas devem servir como indícios para a produção de informações e explicações específicas sobre a sociedade que as produziu, devemos aceitar que o uso mais adequado dos códices pictoglíficos é aquele que procura entendê-los como vestígios de um fato social mais amplo e único, isto é, que envolve as instituições que os produziram e as complexas e hierarquizadas sociedades mesoamericanas, pois de ambas dependiam as formas de composição, os temas, os formatos, a gramática, os usos e os objetivos das mensagens codificadas em tais manuscritos. Sendo assim, parece que o segundo e terceiro grupos buscaram, de forma mais sistemática, entender os possíveis sentidos e significados dos códices pictoglíficos pari passu com a compreensão das especificidades de seu contexto histórico-cultural, ou, melhor ainda, como indícios desse contexto. Os estudos produzidos por esses dois grupos, sobretudo pelo terceiro, mostram mais claramente que as imagens pictoglíficas não são, elas próprias, geradoras ou portadoras de sentidos imanentes, mas suportes de significados socialmente 
atribuídos, isto é, que se apresentavam em meio de padrões culturais e situações sociais muito específicas.

Em segundo lugar, porque os estudiosos do terceiro grupo consideram o sistema mixteco-nahua como uma escrita e seus registros como textos, o que se constitui como uma opção teórico-metodológica que influencia as análises e procedimentos adotados. Ao considerarem os registros mixteco-nahuas como textos, isto é, como entidades com sua própria inteireza, mostram que os sentidos de suas partes, isso é, de seus conjuntos de imagens e glifos, dependem de seu valor posicional e do tipo de escrito em que se encontram, entre outras coisas. Por outro lado, ao considerarem os conjuntos pictoglíficos como partes de um sistema de escrita, os tratam como signos para grafar o pensamento e a fala cujos significados conformariam um repertório relativamente bem delimitado e estável para os que compartilhavam suas convenções.

Alguns desses estudiosos, entre os quais podemos destacar Gordon Brotherston, chegam inclusive a apontar a necessidade de uma redefinição do conceito de escrita entre as ciências humanas, que passaria a abranger qualquer sistema de representação visual ou táctil do pensamento ou da fala com convenções, usos, lógica e gramática bem estabelecidos em determinada sociedade ou camada social. Tais características garantiriam uma qualidade básica a qualquer sistema de escrita: a permanência e a reabilitação de significados relativamente bem determinados e socialmente compartilhados a partir da decodificação de seus registros. ${ }^{75}$ Os estudos promovidos pelos estudiosos agrupados no terceiro grupo, evocados aqui de forma exemplar, pois há dezenas de outros pesquisadores que tratam os códices de maneira semelhante, não deixam dúvida que o sistema mixteco-nahua e seus manuscritos pictoglíficos encaixam-se nesse tipo de definição de escrita.

\footnotetext{
${ }^{75}$ Não se trata, portanto, de analisar os tipos de escrita e tentar estabelecer processos de evolução auto-referenciados, isto é, que considerem os sistemas escriturários isoladamente de seus usos sociais: na Mesoamérica, as escritas pictoglíficas não eram cronológica ou evolutivamente anteriores às predominantemente fonéticas, como a maia e a zapoteca, uma das mais antigas da região. Ao contrário, trata-se de entender as capacidades, possibilidades e usos sociais de cada sistema. Por exemplo, se o objetivo fosse uma circulação regionalmente mais ampla, o sistema mixteco-nahua levava vantagem sobre o maia, pois poderia ser decodificado por falantes de diversas línguas, como o nahuatl, o otomie, o totonaco, o cuicateco, o chocho, o mixteco, o zapoteco e o tlapaneco.
} 


\section{Bibliografia}

BERNAND, Carmen \& GRUZINSKI, Serge. De la idolatría. Una arqueologia de las ciencias religiosas. Tradução Diana Sánchez F. México: Fondo de Cultura Económica, 1992 (Sección de Obras de Historia).

História do Novo Mundo. Da descoberta à conquista uma experiência européia (1492-1550). Tradução Cristina Muracho. São Paulo: Edusp, 1997.

BONIFAZ NUÑO, Rubén. Cosmogonía antigua mexicana. México: Coordinación de Humanidades - UNAM, 1995 (Seminario de Estudios Para la Descolonización de México).

Imagen de Tláloc. México: El Colégio Nacional, 1992.

Olmecas: esencia y fundación - Hipótesis iconográfica y textual. México: El Colegio Nacional, 1992.

BROHERSTON, Gordon. European scholasticism analysed in aztec terms: the case of the Codex Mexicanus. In: Boletim do Centro de Estudos e Documentação sobre o Pensamento Antigo Clássico, Helenístico e sua Posteridade Histórica (CPA). Campinas: Instituto de Filosofia e Ciências Humanas - UNICAMP, ano IV, nº. 5/6, pp. 169-180, janeiro/dezembro de 1998.

Indigenous intelligence in Spain's American Colony. In: Forum for modern language studies. St Andrews (Escócia): University of St Andrews Press, vol. XXXVI, nº. 3, 2000, pp. 241-253.

La América indígena en su literatura: los libros del cuarto mundo. Tradução de Teresa Ortega Guerrero e Mónica Utrilla. México: Fondo de Cultura Económica, 1997 (Sección de Obras de Historia).

La visión americana de la conquista. In: PIZARRO, Ana. América Latina: palavra, literatura e cultura, vol. 1. São Paulo: Fundação Memorial da América Latina \& Campinas: Editora da Unicamp, 1993. pp. 63-84.

Painted books from Mexico. Codices in UK collections and the world they represent. Londres: British Museum Press, 1995.

Gordon. The year 3113 BC and the Fifth Sun of Mesoamerica: an orthodox reading of the Tepexic Annals (Codex Vindobonensis observe). In: AVENI, Anthony F. \& BROTHERSTON, Gordon (editores). Calendars in Mesoamerica and Peru - Native American computations of time Proceedings 44 International Congress of Americanists, Manchester 1982. Oxford: BAR, 1983 (International Series, 174). pp. 167-220. 
The year in the Mexican codices: the nature and structure of the eighteen feasts. Texto datilografado, 2002 (prestes a ser publicado em Londres sob o título de Models of the year in Mesoamerican texts, na série British Museum Occasional Papers.

Traduzindo a linguagem visível da escrita. In: Literatura e Sociedade.

São Paulo: Departamento de Teoria Literária e Literatura Comparada da FFLCH - USP, nº 4, 1999, pp. 78-91.

CASO, Alfonso. El pueblo del Sol. 13 edição, México: Fondo de Cultura Económica, 1994 (Colección Popular, nº 104).

Los calendarios prehispánicos. México: Instituto de Investigaciones Históricas - UNAM, 1967 (Serie de Cultura Náhuatl - Monografías 6).

Reyes y reinos de la Mixteca. 2 vols. México: Fondo de Cultura Económica, 1977-1979.

COE, Michael D. El desciframiento de los glifos mayas. Tradução Jorge Ferreiro. 4ª reimpressão, México: Fondo de Cultura Económica, 2001 (Sección de Obras de Antropología).

FLORESCANO, Enrique. Memoria mexicana. $2^{\mathrm{a}}$. edição, México: Fondo de Cultura Económica, 1994.

Mito e história en la memoria mexicana - Texto datilografado do discurso apresentado em seu ingresso na Academia Mexicana de História como membro de número, em 18 de julho de 1989.

Sobre la naturaleza de los dioses mesoamericanos. Disponível em: <http://www.nexos.com.mx/nexos/dic228/temcen/tc1.html >. Consultado em 23 de março de 1998.

GALARZA, Joaquín. In amoxtli in tlacatl - el libro, el hombre. Códices y vivencias. México: Tava Editorial, 1992 (Colección Códices Mesoamericanos).

Los códices mexicanos. In: Arqueología Mexicana. Códices prehispánicos. Direção científica Joaquín García-Bárcena e outros. México: Editorial Raíces \& INAH \& CONACULTA, vol. IV, nº 23, 1997, pp. 6-13.

GARIBAY K., Ángel María. Diego Durán y su obra. In: DURÁN, Fray Diego. Historia de las Indias de Nueva España e islas de la tierra firme. 2' edição, México: Editorial Porrúa, 2 volumes, 1984. pp. IX-XLVII (Biblioteca Porrúa, no. 36). . Historia de la literatura náhuatl. México: Editorial Porrúa, 1992 (Colección Sepan Cuantos, nº. 626). 
Proemio general. In: SAHAGÚN, Fray Bernardino de, Historia general de las cosas de Nueva España. 9'. edição, México: Editorial Porrúa, 1997. pp. 1-14 (Colección Sepan Cuantos, nº 300).

Teogonía e historia de los mexicanos: tres opúsculos del siglo XVI. 5. edição, México: Editorial Porrúa, 1996 (Colección Sepan Cuantos, nº. 37). GIBSON, Charles \& GLASS, John B. A census of Middle American prose manuscripts in the native historical tradition. In: WAUCHOPE, Robert (editor geral) \& CLINE, Howard F. (editor do volume). Handbook of Middle American Indians. vol. 15. Austin e Londres: University of Texas Press, 1975. pp. 322-400.

GIBSON, Charles. A survey of Middle American prose manuscripts in the native historical tradition. In: WAUCHOPE, Robert (editor geral) \& CLINE, Howard F. (editor do volume). Handbook of Middle American Indians. vol. 15. Austin e Londres: University of Texas Press, 1975. pp. 311-321.

GLASS, John B. \& ROBERTSON, Donald. A census of native Middle American pictorial manuscripts. In: WAUCHOPE, Robert (editor geral) \& CLINE, Howard F. (editor do volume). Handbook of Middle American Indians. vol. 14. Austin e Londres: University of Texas Press, 1975. pp. 81-310.

GLASS, John B. A survey of native Middle American pictorial manuscripts. In: WAUCHOPE, Robert (editor geral) \& CLINE, Howard F. (editor do volume). Handbook of Middle American Indians. vol. 14. Austin e Londres: University of Texas Press, 1975. pp. 3-80.

Annotated references. In: WAUCHOPE, Robert (editor geral) \& CLINE, Howard F. (editor do volume). Handbook of Middle American Indians. vol. 15. Austin e Londres: University of Texas Press, 1975. pp. 537-724.

GRUZINSKI, Serge. La colonización de lo imaginario. Sociedades indígenas y occidentalización en el México español, siglos XVI - XVIII. Tradução Jorge Ferreiro. 2ª edição, México: Fondo de Cultura Económica, 1995 (Sección de Obras de Historia).

La guerra de las imágenes: De Cristóbal Colón a "Blade Runner" (1492-2019). Tradução Juan José Utrilla. México: Fondo de Cultura Económica, 1994 (Sección de Obras de Historia).

HEYDEN, Doris. Las cuevas de Teotihuacan. In: Arqueología Mexicana. Ritos del México prehispánico. Direção científica Joaquín García-Bárcena e outros. México: Editorial Raíces \& INAH \& CONACULTA, vol. VI, nº. 34, 1998, pp. 18-27. 
México: orígenes de un símbolo (versión adaptada e ilustrada). México: CONACULTA \& INAH, 1998.

Tezcatlipoca en el mundo náhuatl. In: Estudios de Cultura Nahuatl. Editor Miguel León Portilla. México: Instituto de Investigaciones Históricas - UNAM, vol. 19, 1989, pp. 83-93.

KIRCHHOFF, Paul. Mesoamérica: sus límites geográficos, composición étnica y caracteres culturales. In: Suplemento de la Revista Tlatoani. México: Sociedad de Alumnos de la Escuela Nacional de Antropología e Historia, nº 3, 1960.

LEÓN PORTILLA, Miguel. A Mesoamérica antes de 1519. In: BETHEL1, Leslie. História da América Latina: América Latina colonial, vol. I. Tradução Maria Clara Cescato. 2' edição, São Paulo: Edusp \& Brasília: Fundação Alexandre Gusmão, 1998. pp. 25-61.

Códices - Los antiguos libros del Nuevo Mundo. México: Aguilar, 2003. El destino de la palabra: de la oralidad y los códices mesoamericanos a la escritura alfabética. México: El Colégio Nacional \& Fondo de Cultura Económica, 1997.

Literaturas indígenas de México. $2^{\mathrm{a}}$ edição, México: Fondo de Cultura Económica \& Editorial Mapfre, 1992.

Los nobres de lugar en náhuatl. Su morfología, sintaxis y representción glífica. In: Estudios de cultura náhuatl. Editores Miguel León Portilla e outros. México: Instituto de Investigaciones Históricas - UNAM, vol. 15, 1982, pp. 37-72.

Toltecáyotl: aspectos de la cultura náhuatl. $5^{\text {a }}$. edição, México: Fondo de Cultura Económica, 1995.

Visión de los vencidos: relaciones indígenas de la conquista. $2^{\mathrm{a}}$. edição, México: UNAM, 1961 (Biblioteca del Estudiante Universitario, vol. 81).

LONGHENA, María. Maya script: a civilization and its writing. Tradução Rosanna M. Giammanco Fongia. Nova Iorque: Abbeville Press, 2000.

LÓPEZ AUSTIN, Alfredo. Hombre-dios: religión y política en el mundo náhuatl. México: Instituto de Investigaciones Historicas - UNAM, 1973 (Serie de Cultura Náhuatl - Monografías 15).

Los milénios da la religión mesomericana (parte I). In: Arqueología Mexicana. Los olmecas. La religión en Mesoamérica. Direção científica 
Joaquín García-Bárcena e outros. México: Editorial Raíces \& INAH \& CONACULTA, vol. II, nº. 12, 1995, pp. 4-15.

Los ritos: un juego de definiciones. In: Arqueología Mexicana. Ritos del México prehispánico. Direção científica Joaquín García-Bárcena e outros. México: Editorial Raíces \& INAH \& CONACULTA, vol. VI, nº. 34, 1998, pp. 4-17.

Los rostros de los dioses mesoamericanos. In: Arqueología Mexicana. Los dioses de Mesoamérica. Direção científica Joaquín García-Bárcena e outros. México: Editorial Raíces \& INAH \& CONACULTA, vol. IV, nº 20, 1996, pp. 6-19.

MATOS MOCTEZUMA, Eduardo. Muerte a filo de obsidiana. Los nahuas frente a la muerte. 4 edição, México: Asociación de Amigos del Templo Mayor \& Fondo de Cultura Económica, 1997 (Sección de Obras de Antropología). Vida y muerte en el Templo Mayor. $3^{\mathrm{a}}$ - edição, México: Fondo de Cultura Económica \& Asociación de Amigos del Templo Mayor, 1998 (Sección de Obras de Antropología).

MOLINA, Alonso de. Vocabulario en lengua castellana y mexicana y mexicana y castellana. Estudo preliminar Miguel León Portilla. 4ª edição, México: Editorial Porrúa, 2001 (Biblioteca Porrúa nº. 44).

NAVARRETE LINARES, Federico. Las fuentes indígenas: más allá de la dicotomía entre historia y mito. Disponível em <www.fflch.usp.br/dh/ceveh/ public html/biblioteca/artigos/FN-P-A-historiaymito.html> Consultado em 09 de dezembro de 2000.

Los libros quemados y los libros sustituidos. Disponível em: < $\underline{\text { http:// }}$ www.fflch.usp.br/dh/ceveh/public html/biblioteca/artigos/fn-a-e-livrosquei.html> Consultado em 09 de dezembro de 2000.

Mito, historia y legitimidad política: las migraciones de los pueblos del Valle de México. Tese de doutoramento. Orientador Alfredo López Austin. México: Facultad de Filosofía y Letras - UNAM, 2000.

PIÑA CHAN, Román. Quetzalcoatl. Serpente emplumada. $5^{\text {a }}$. reimpressão, México: Fondo de Cultura Económica, 1992 (Sección de Obras de Antropología).

REYES GARCÍA, Luis. Dioses y escritura pictográfica. In: Arqueología Mexicana. Códices prehispánicos. Direção científica Joaquín García-Bárcena e outros. México: Editorial Raíces \& INAH \& CONACULTA, vol. IV, nº. 23, 1997, pp. 24-33. 
SANTOS, Eduardo Natalino dos. As tradições históricas indígenas diante da conquista e colonização da América: transformações e continuidades entre nahuas e incas. In: Revista de História. Departamento de História, FFLCH-USP. São Paulo: Humanitas \& FFLCH-USP, $n^{\circ} .150,1^{\circ}$. semestre de 2004, pp. 157-207.

Calendário, cosmografia e cosmogonia nos códices e textos nahuas do século XVI. Tese de doutorado. Orientadora Janice Theodoro da Silva. São Paulo: Departamento de História da FFLCH - USP, 2005.

Deuses do México indígena. Estudo comparativo entre narrativas espanholas e nativas. São Paulo: Editora Palas Athena, 2002.

Recebido em 27/09/2005 e aprovado em 13/10/2005. 